\title{
遠距離大規模地震記録を用いた足柄平野の 広周波数帯域地震応答
}

\author{
東京電力株式会社電力技術研究所耐震グループ* 植 竹 富 一 \\ 東京大学地震研究所 $* *$ 工 藤 一 嘉
}

\section{Evaluation of Site Effects in a Wide Frequency Band at Ashigara Valley, Japan, Using Strong Motion Records from Remote and Large Events}

\author{
Tomiichi Uetake \\ Seismic Design Group, Power Engineering R\&D Center, Tokyo Electric Power \\ Company, 4-1, Yokohama 230-8510, Japan \\ Kazuyoshi Kudo \\ Earthquake Research Institute, University of Tokyo, 1-1-1, Yayoi, Bunkyo-ku, \\ Tokyo 113-0032, Japan
}

(Received October 13, 1997; Accepted January 8, 1998)

\begin{abstract}
Tectonics and geological environments in and around Ashigara valley are very complex, especially surrounding rock outcrop sites are not on the same geology. Therefore, it is our concern to find the best reference site and to determine the seismic response at a site in the valley. We had an opportunity to use the ground motion data sets from the very far $(>700 \mathrm{~km})$ and large $(>M 7)$ events to compare the rock sites motion as well as the response of sediments site. Advantages of using far and large events are that the source and path effects will be common with a sufficient approximation and that the ground motions of wide frequency band content are expected. Selecting one rock site, seismic responses of the sediment sites and rock sites were determined in terms of frequency as well as time domain amplitudes applying band-pass filtering techniques. Results are as follows; (1) Spatial distribution of seismic responses as a function of frequency in the valley are displayed. The spatial distribution of amplitude in low frequency range under $0.2 \mathrm{~Hz}$ is relatively simple and similar to Bouguer anomaly map. The characteristics of spatial distribution in high frequency are more complex. (2) Deviations of spectral amplitude at rock sites were determined by taking the spectral ratio of the site to the average spectra of 6 rock sites. Only lower frequency motion than $0.07 \mathrm{~Hz}$ are the same and the deviations of spectral ratio are a factor of 2 in the frequency range of $0.1-10 \mathrm{~Hz}$. (3) The level of spectral ratios of very far earthquakes are more stable than that of near earthquakes in $0.1-10 \mathrm{~Hz}$.
\end{abstract}

Key words: Site response, Reference site, Spectral ratio, Strong motion records, Ashigara valley.

\section{§1.はじめに}

1995 年兵庫県南部地震では, 震度 7 の被害域が帯状 に分布し, その一因と考元られる地震動強さの分布之堆 積層構造の関係が改めて注目された。堆積層構造が地震

* 于230-8510 横浜市鶴見区江ヶ崎町 4-1

** =113-0032 東京都文京区弥生 1-1-1
動に与える影響については, 従来から岩盤点と堆積層上 の点の比較観測を含んだ強震計によるアレイ観測が試み られ [干場・他 (1988), Kit AGaw a et al. (1988), Kudo et al. (1988), Омоте et al. (1980), Pitilakis (1995), Real and TUCKER (1988), 笹谷 - 他 (1990), Steidl et al. (1996), WEN et al. (1995) 等], 堆積層上での地震動の増 幅や後続波群の発達性状などが検討されている. 
堆積層上の地震動特性を評価するための現実的な方法 として，堆積層への入射波と見なし得る岩盤点の記録が 参照あるいは基準波形として利用される，また，適当な 岩盤記録が得られない場合は，別途推定した基盤入射波 との比で観測点特性を定義する手法 [例えば，木下・他 (1986)，山本・他 (1995)］や， S 波入射の表層での水平 動と上下動の比を利用する手法（Receiver function; 例 えば，LANGSTON (1979)) などが提案されている。ささら に，逆解析により観测点特性を含む各要因を同時に求め る方法の有用性む指摘されている [例えば，岩田・入倉 (1986), KATo et al. (1992)]，岩盤での記録を参照波形と することは，標準的評価と考えられ，上で述べた種々の 手法の精度調查にも利用される [FIELD and JACOB (1995)]. しかし, 強震動デー夕は比較的近距離の地震 によるものが多いため, 参照点と評価対象地点との距離 や震源方位の差を無視できない場合がある，この場合， 岩盤点での記録を堆積層への入射波と見なすこの手法の 前提が崩れることとなる，従って，観測点特性以外の要 因に関しては，相殺あるいは無視できるデータセットの
利用が，より確かなサイト特性の評価につながる．本論 文では，観測点からきわめて遠方で発生した地震の記録 を用いて観測点特性の抽出を試みた，遠方の地震を使う ことにより，震源を点震源と考えることができ，岩盤サ イトを含む観測網全体への同一の震源放射特性をむつ平 面波入射を仮定することができる，さらに，対象となる 地震は, 必然的にマグニチュード $(M)$ の大きな地震であ ることから長周期側まで $\mathrm{SN}$ 比が良く, 観測点の特性を 長周期まで論じることができる。

本論文では, 神奈川県西部の足柄平野に展開された強 震観測網 [Kudo et al. (1988)] で得られたデー夕を用い て, 周波数帯域毎の波形の変化及び岩盤点に対する各観 測点のスペクトル比から堆積層の影響を評価する，足柄 平野周辺は，伊豆半島の本州への衝突，相模卜ラフから のフィリピン海プレートの沈み込み，国府津一松田断層 の存在等, テクトニクス的に複雑な環境にあり [例えば, YAMAZAKI (1992)], 過去に数多くの被害地震が発生し, さらに，近い将来の地震発生の可能性が指摘されている [石橋 (1993)].したがって，この地域の地盤特性を把握

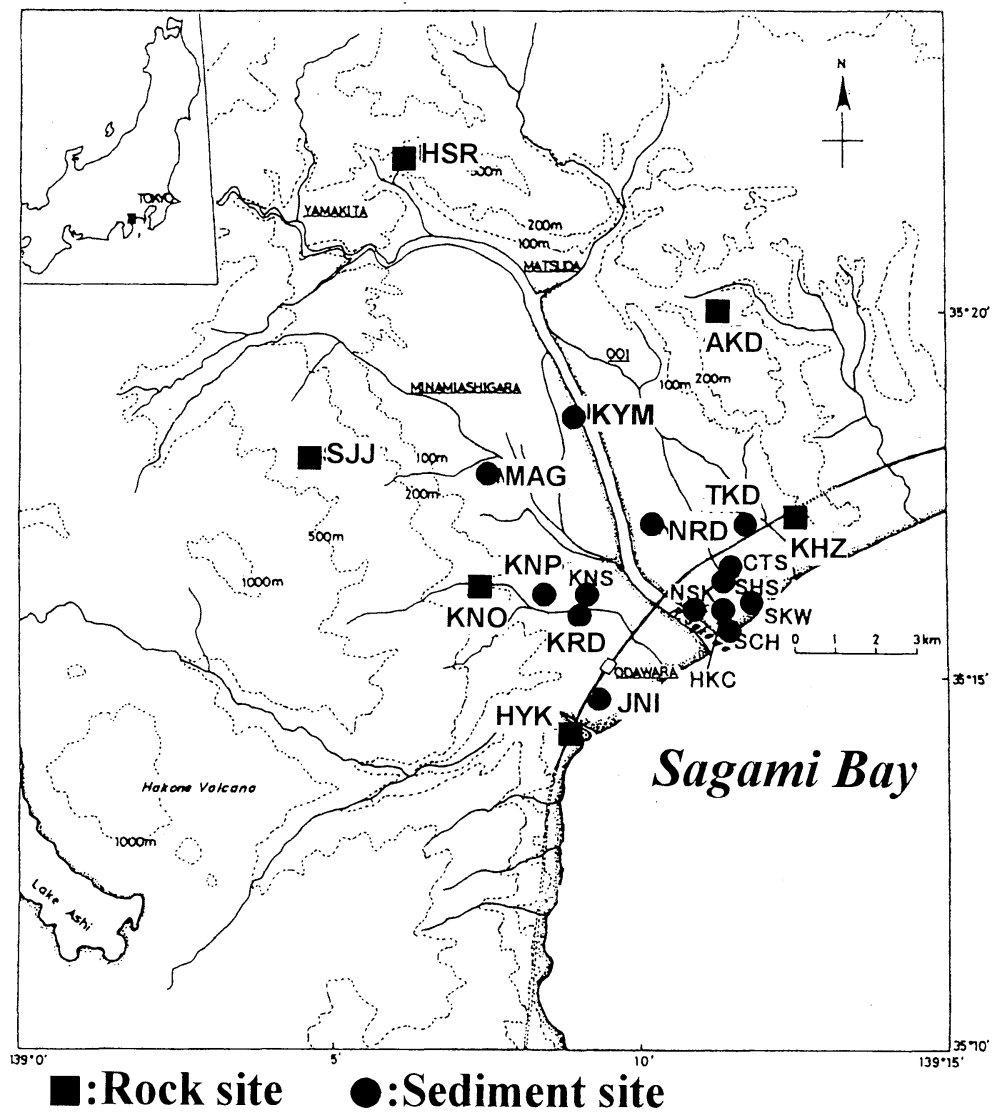

Fig. 1. Strong motion accelerograph array in Ashigara valley. 
しておくことは, 地震防災上の観点からあ重要である.

足柄平野南西部の久野地区は, 表層地質の影響 [Effects of Surface Geology (ESG)] 検討のための国際 テストサイトとして, 地震動の目隠し予測 (Blind prediction) テストが行われた場所である [Japanese Working Group on ESG (JESG), (1991)]. この予測実験の結 果から，(1) 予測結果のばらつきの原因，(2) 地盤への入 力の問題，(3) 地盤応答への $2 \cdot 3$ 次元地下構造の影響の 問題，(4) 地盤の非線形性の問題，という今後解決すべき 4 つの問題点が指摘されている [例えば, Kudo and SAWADA (1992)]. 本論文では, 上記 (2) に関連して地震 動評価に重要となる基準観測点に関する問題についても 議論を行う.

\section{§ 2. 足柄平野の観測網}

足柄平野は, 神奈川県西部に位置し, 西は箱根火山, 北は丹沢山地，東は大磯丘陵，南は相模湾に囲まれた東

Table 1. Strong motion observation stations of Earthquake Research Institute, the University of Tokyo in Ashigara valley.

\begin{tabular}{llllll}
\hline Code & Lat.(deg.) & Lon.(deg.) & Surface Geology & Setting point \\
\hline HYK & $35.2383 \mathrm{~N}$ & $139.1464 \mathrm{E}$ & andesite & ground level(G.L.) \\
CTS & $35.2746 \mathrm{~N}$ & $139.1915 \mathrm{E}$ & sandy soil & G.L., $-10,-30,-100,-467 \mathrm{~m}$ \\
KNO & $35.2706 \mathrm{~N}$ & $139.1250 \mathrm{E}$ & andesite & G.L.,-22m \\
SJJ & $35.2997 \mathrm{~N}$ & $139.0786 \mathrm{E}$ & andesite & G.L. \\
HSR & $35.3672 \mathrm{~N}$ & $139.1039 \mathrm{E}$ & tuff breccia & G.L. \\
AKD & $35.3331 \mathrm{~N}$ & $139.1896 \mathrm{E}$ & basalt & G.L. \\
KHZ & $35.2861 \mathrm{~N}$ & $139.2106 \mathrm{E}$ & tuff breccia & G.L. \\
NSK & $35.2650 \mathrm{~N}$ & $139.1817 \mathrm{E}$ & sandy soil & G.L. \\
NRD & $35.2839 \mathrm{~N}$ & $139.1700 \mathrm{E}$ & sandy soil & G.L. \\
KYM & $35.3103 \mathrm{~N}$ & $139.1511 \mathrm{E}$ & sandy soil & G.L. \\
SKW & $35.2664 \mathrm{~N}$ & $139.1947 \mathrm{E}$ & sandy soil & G.L. \\
TKD & $35.2847 \mathrm{~N}$ & $139.1947 \mathrm{E}$ & sandy soil & G.L.,-40m \\
MAG & $35.2953 \mathrm{~N}$ & $139.1256 \mathrm{E}$ & loam & 1F of building \\
JNI & $35.2464 \mathrm{~N}$ & $139.1600 \mathrm{E}$ & sandy soil & 1F of building \\
KNP & $35.2696 \mathrm{~N}$ & $139.1402 \mathrm{E}$ & loam & G.L. \\
KNS & $35.2666 \mathrm{~N}$ & $139.1516 \mathrm{E}$ & humus soil & G.L.,-30,-97m \\
KRD & $35.2646 \mathrm{~N}$ & $139.1506 \mathrm{E}$ & humus soil & B1F of building \\
SCH & $35.2616 \mathrm{~N}$ & $139.1904 \mathrm{E}$ & sandy soil & 1F of building \\
HKC & $35.2653 \mathrm{~N}$ & $139.1883 \mathrm{E}$ & sandy soil & B1F of building \\
SHS & $35.2715 \mathrm{~N}$ & $139.1891 \mathrm{E}$ & sandy soil & 1F of building \\
\hline
\end{tabular}

西 $4 \mathrm{~km}$, 南北 $12 \mathrm{~km}$ 程度の沖積平野である. 足柄平野 の強震観測網は，Fig. 1 に示すように平野を取り囲む山 地及び丘陵上の岩盤観测点 6 点 (HYK, KNO, SJJ, HSR, $\mathrm{AKD}, \mathrm{KHZ}$ ), 平野内の堆積層上観测点 14 点 (JNI, KNP, KNS, KRD, NSK, SKW, CTS, SCH, SHS, HKC, TKD, NRD, KYM, MAG) からなっている. このうち $\mathrm{KNO}$ $\mathrm{KNP}, \mathrm{KNS}$ の 3 点は, ESG 研究の一環である目隠し予 測に使われた観测点である [JESG (1991)]． 各観測点の 概要を Table 1 に示す。平野部の観測点の表層地質は, 多くが砂質土であるが，KRD, KNS は粘性土（腐植土）, KNP, MAG はロームである．また，岩盤点では，HSR， $\mathrm{KHZ}$ は足柄層群の凝灰角䃇岩, KNO, SJJ は箱根古期外 輪山溶岩， AKD は丹沢層群の玄武岩と観測点毎に異 なった表層地質となっている。

$\mathrm{PS}$ 検層による地震計設置位置での $\mathrm{S}$ 波速度 $\left(V_{\mathrm{s}}\right)$ は CTS の G.L. 及び- $10 \mathrm{~m}$ で $110 \mathrm{~m} / \mathrm{s},-30 \mathrm{~m}$ で 250 $\mathrm{m} / \mathrm{s},-100 \mathrm{~m}$ で $500 \mathrm{~m} / \mathrm{s}$, そして $-467 \mathrm{~m}$ で $1260 \mathrm{~m} /$ $\mathrm{s}$ 程度となっているが，YAMAZAKI (1992)によればこの 深さであ第四紀層の基底には達していない，岩盤点の KNO では, G.L. で $V_{\mathrm{s}}=800 \mathrm{~m} / \mathrm{s},-22 \mathrm{~m}$ で $V_{\mathrm{s}}=1200$ $\mathrm{m} / \mathrm{s}$ となっている. また，TKD では G.L. で $V_{\mathrm{s}}=110$ $\mathrm{m} / \mathrm{s},-40 \mathrm{~m}$ で $V_{\mathrm{s}}=350 \mathrm{~m} / \mathrm{s}$, KNS では G.L. で $V_{\mathrm{s}}=$ $65 \mathrm{~m} / \mathrm{s},-30 \mathrm{~m}$ で $V_{\mathrm{s}}=400 \mathrm{~m} / \mathrm{s},-97 \mathrm{~m}$ で $V_{\mathrm{s}}=700$ $\mathrm{m} / \mathrm{s}$ となっている.

観測に使用している収録装置は, SMAD-3 シリーズ ((株)アカシ) で，加速度センサーはV401BT である. 記録器の特性は全て $\mathrm{DC} \sim 30 \mathrm{~Hz}$ まで平坦であり, サン プリング周波数は $100 \mathrm{~Hz}$ で，最大加速度 $2000 \mathrm{~cm} / \mathrm{s} / \mathrm{s}$ まで計測できる. A/D 変換は 16 ビットを用いている が，見かけのダイナミックレンジを大きくするために下 位 2 ビットを 1 サンプル毎のゲインレンジ $(\times 1, \times 1 / 4$, $\times 1 / 16)$ に用いている。 つまり，通常は最小有効加速度 $0.015 \mathrm{~cm} / \mathrm{s} / \mathrm{s}$ で, 最大 $125 \mathrm{~cm} / \mathrm{s} / \mathrm{s}$ となっており, 125

Table 2. Long distance earthquakes used in this study.

Origin time $(\mathrm{y} / \mathrm{m} / \mathrm{d} h: \mathrm{m}: \mathrm{s})$ Latitude Longitude depth $M$ Event name

$\begin{array}{llllllc}1993 / 01 / 15 & 20: 06: 07.2 & 42.917 \mathrm{~N} & 144.357 \mathrm{E} & 101 \mathrm{~km} & 7.8 & 1993 \text { Kushiro-oki } \\ 1994 / 07 / 22 & 03: 36: 31.5 & 42.277 \mathrm{~N} & 133.550 \mathrm{E} & 552 \mathrm{~km} & 7.6 & \text { Near Vladivostok } \\ 1994 / 10 / 04 & 22: 22: 56.9 & 43.372 \mathrm{~N} & 147.678 \mathrm{E} & 28 \mathrm{~km} & 8.1 & 1994 \text { Hokkaido toho-oki } \\ 1994 / 12 / 28 & 21: 19: 20.9 & 40.427 \mathrm{~N} & 143.748 \mathrm{E} & 0 \mathrm{~km} & 7.5 & 1994 \text { Sanriku haruka-oki }\end{array}$




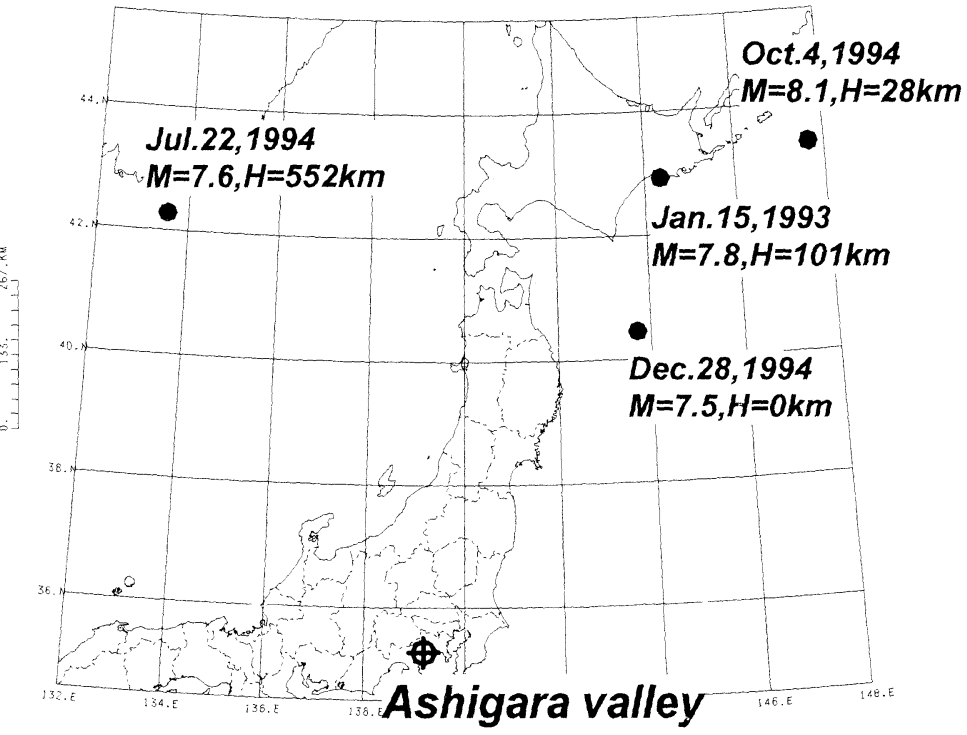

Fig. 2. Location map of earthquakes and the observation network.

Table 3. Peak Ground Acceleration of each record. Epicentral distance and azimuth are calculated for CTS.

Peak Ground Acc. (unit in $\mathrm{cm} / \mathrm{s} / \mathrm{s}$ )

\begin{tabular}{|c|c|c|c|c|c|c|c|c|c|c|c|c|}
\hline & \multicolumn{3}{|c|}{1993.1 .15} & \multicolumn{3}{|c|}{1994.7 .22} & \multicolumn{3}{|c|}{1994.10 .4} & \multicolumn{3}{|c|}{1994.12 .28} \\
\hline & \multicolumn{3}{|c|}{ Kushiro-oki } & \multicolumn{3}{|c|}{ Near Vladivostok } & \multicolumn{3}{|c|}{ Hokkaido Toho-oki } & \multicolumn{3}{|c|}{ Sanriku haruka-oki } \\
\hline delta & \multicolumn{3}{|c|}{$958 \mathrm{~km}$} & \multicolumn{3}{|c|}{$919 \mathrm{~km}$} & \multicolumn{3}{|c|}{$1158 \mathrm{~km}$} & \multicolumn{3}{|c|}{$698 \mathrm{~km}$} \\
\hline \multirow[t]{2}{*}{ azimth } & \multicolumn{3}{|c|}{206 deg. } & \multicolumn{3}{|c|}{150 deg. } & \multicolumn{3}{|c|}{217 deg. } & \multicolumn{3}{|c|}{214 deg. } \\
\hline & NS & EW & UD & NS & EW & UD & NS & EW & UD & NS & EW & UD \\
\hline HSR & 2.1 & 3.2 & 1.9 & 2.4 & 1.9 & 1.5 & 4.0 & 4.5 & 2.5 & 1.5 & 1.7 & 1.1 \\
\hline SJJ & - & - & - & 1.6 & 1.8 & 1.0 & 3.6 & 4.8 & 2.9 & 2.2 & 1.8 & 1.5 \\
\hline AKD & 1.8 & 1.6 & 1.0 & - & - & - & - & - & - & 1.8 & 1.5 & 1.0 \\
\hline KNO & 2.6 & 1.8 & 1.6 & 1.8 & 1.0 & 1.0 & 3.7 & 2.9 & 2.4 & 2.2 & 2.3 & 1.1 \\
\hline $\mathrm{KHZ}$ & 2.5 & 2.1 & 1.3 & - & - & - & 2.9 & 3.5 & 2.0 & 2.6 & 1.8 & 1.5 \\
\hline HYK & 4.7 & 4.4 & 1.6 & 1.6 & 1.8 & 0.9 & 6.7 & 4.8 & 2.2 & 2.8 & 3.7 & 1.8 \\
\hline KNP & - & - & - & - & - & - & 15.7 & 10.6 & 7.3 & - & - & - \\
\hline KNS & 10.2 & 10.1 & 3.5 & 9.0 & 4.5 & 2.1 & 14.7 & 12.0 & 5.3 & - & - & - \\
\hline KRD & - & - & - & - & - & - & 12.5 & 12.5 & 4.4 & 7.6 & 6.3 & 1.8 \\
\hline $\mathrm{KYM}$ & 4.7 & 7.7 & 2.5 & 2.7 & 3.7 & 1.4 & 7.8 & 7.6 & 2.8 & 4.2 & 2.5 & 1.7 \\
\hline MAG & - & - & - & - & - & - & - & - & - & - & - & - \\
\hline NRD & 8.8 & 8.8 & 3.4 & 6.3 & 6.8 & 3.1 & 11.3 & 14.2 & 6.0 & 8.4 & 7.9 & 3.2 \\
\hline TKD & 9.4 & 8.6 & 2.9 & 5.8 & 6.8 & 1.7 & 12.7 & 20.5 & 5.8 & - & - & - \\
\hline CTS & 7.1 & 7.7 & 3.1 & 5.5 & 5.8 & 1.8 & 12.0 & 11.4 & 4.5 & 6.9 & 7.3 & 2.5 \\
\hline SHS & - & - & - & 4.5 & 4.2 & 1.5 & 10.0 & 11.1 & 4.0 & 7.4 & 5.7 & 1.5 \\
\hline NSK & 5.0 & 5.4 & 1.8 & 3.6 & 3.8 & 1.1 & 6.6 & 8.2 & 2.8 & 5.4 & 4.9 & 1.7 \\
\hline HKC & - & - & - & 3.0 & 3.0 & 1.5 & 6.5 & 9.2 & 3.4 & 4.7 & 3.9 & 1.9 \\
\hline SKW & 6.9 & 7.3 & 2.8 & 3.6 & 3.5 & 1.9 & 9.8 & 10.3 & 5.4 & 4.3 & 5.6 & 2.0 \\
\hline $\mathrm{SCH}$ & - & - & - & - & - & - & 10.8 & 11.5 & 4.1 & 4.8 & 5.0 & 1.8 \\
\hline JNI & 9.4 & 7.7 & 3.6 & - & - & - & 9.9 & 11.7 & 4.4 & - & - & - \\
\hline
\end{tabular}


$\mathrm{cm} / \mathrm{s} / \mathrm{s}$ を超える地震動がきたときには, 1 サンプル毎 に自動的に振幅を $1 / 4$ に,さらに $500 \mathrm{~cm} / \mathrm{s} / \mathrm{s}$ 以上がき たときにはさらに $1 / 4$ して $2000 \mathrm{~cm} / \mathrm{s} / \mathrm{s}$ まで測定でき るようになっている. また，時計の校正には NHK の時 報を用いている.

\section{§3. デー 一}

1993 年釧路沖地震（気象庁マグニチュード $(M)=7.8$, 震源深さ $(H)=101 \mathrm{~km}, \mathrm{CTS}$ からの震央距離 $(\Delta)=958$ $\mathrm{km}), 1994$ 年ウラジオストック付近の地震 $(M=7.6$, $H=551 \mathrm{~km}, \Delta=919 \mathrm{~km}), 1994$ 年北海道東方沖地震 $(M=8.1, H=30 \mathrm{~km}, \Delta=1158 \mathrm{~km}), 1994$ 年三陸はるか 沖地震 $(M=7.5, H=0 \mathrm{~km}, \Delta=698 \mathrm{~km})$ の 4 地震で得ら
れた記録を解析した。気象庁による各地震の諸元を Table 2 に, 足柄平野の位置及び震央位置を Fig. 2 に示 す. いずれも足柄平野の観測点間距離（最大約 $15 \mathrm{~km}$ ) に比べ，はるかに遠い地震であり，基盤をどこにとるか の問題はあるが, 少なくとも岩盤サイトを含む範囲の仮 想基盤に同一の震源放射特性による平面波入射と近似で き，観測網内での距離減衰の影響は無視できる。

Table 3 に各観測点で観測された加速度最大值を示 す. SCH, HKC, SHS の 3 点は 1994 年 3 月に設置され たため, 釧路沖地震の記録は得られていない. また, ト リガーレベルの関係で欠測している地点があり, 特に MAG は 4 地震と屯記録が得られていない. ほとんどの 記録が，最大加速度 $20 \mathrm{~cm} / \mathrm{s} / \mathrm{s}$ 以下であるが，距離の
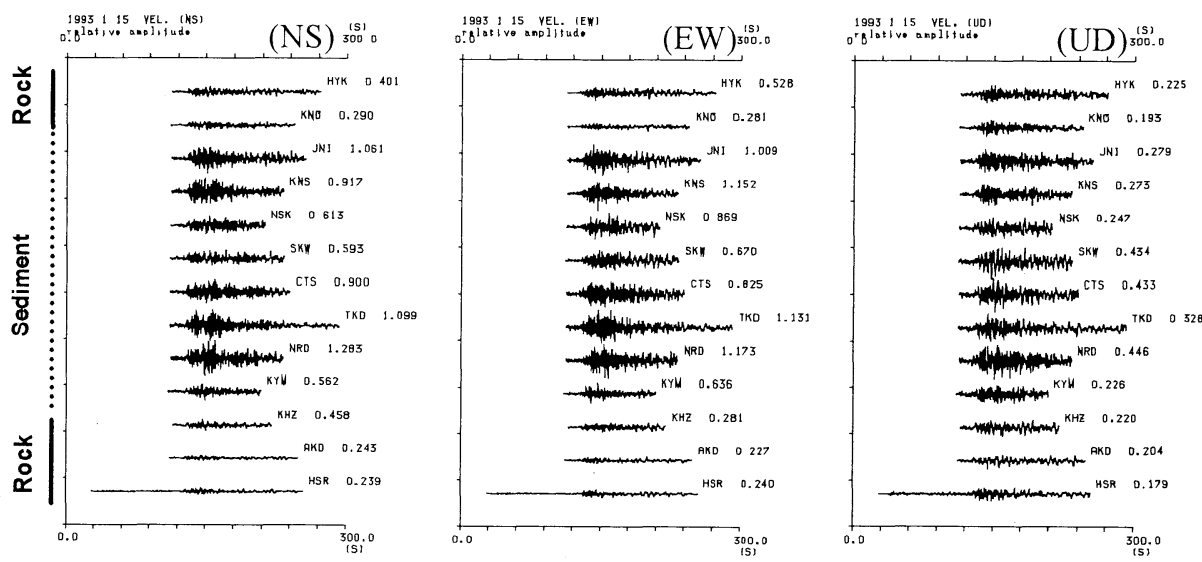

(a) 1993.1.15 Kushiro-oki
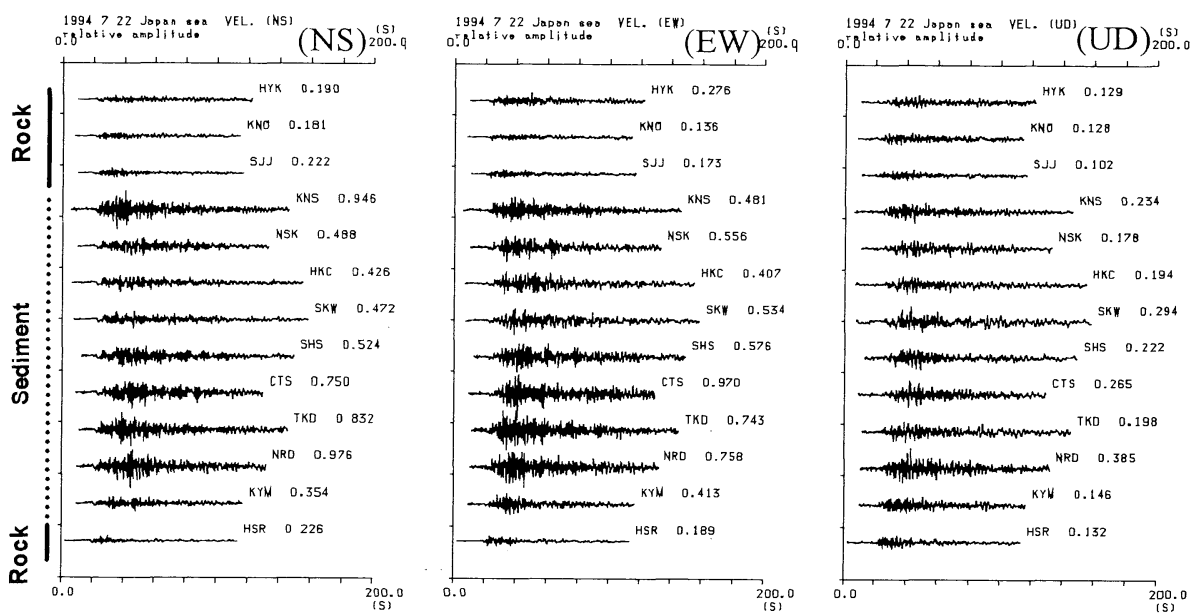

(b) 1994.7.22 Near Vladivostok

Fig. 3. Velocity seismograms observed in Ashigara valley.

(a) 1993 Kushiro-oki earthquake, (b) Near Vladiostok. Each trace was integrated from original acceleration data in the frequency domain. 

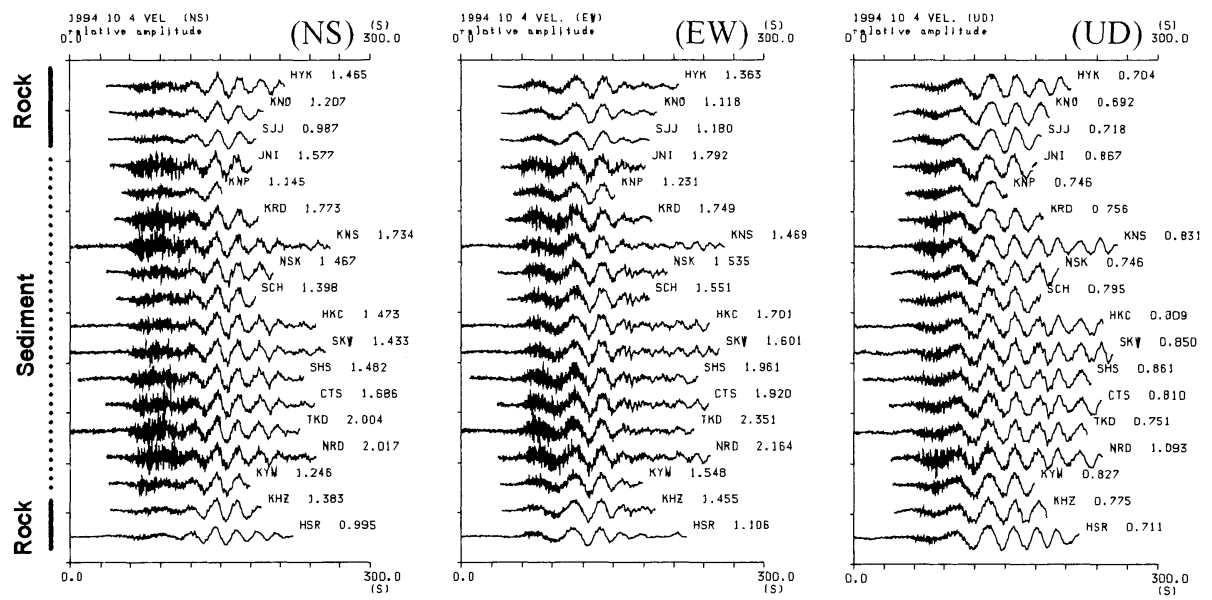

(c) 1994.10.4 Hokkaido Toho-oki
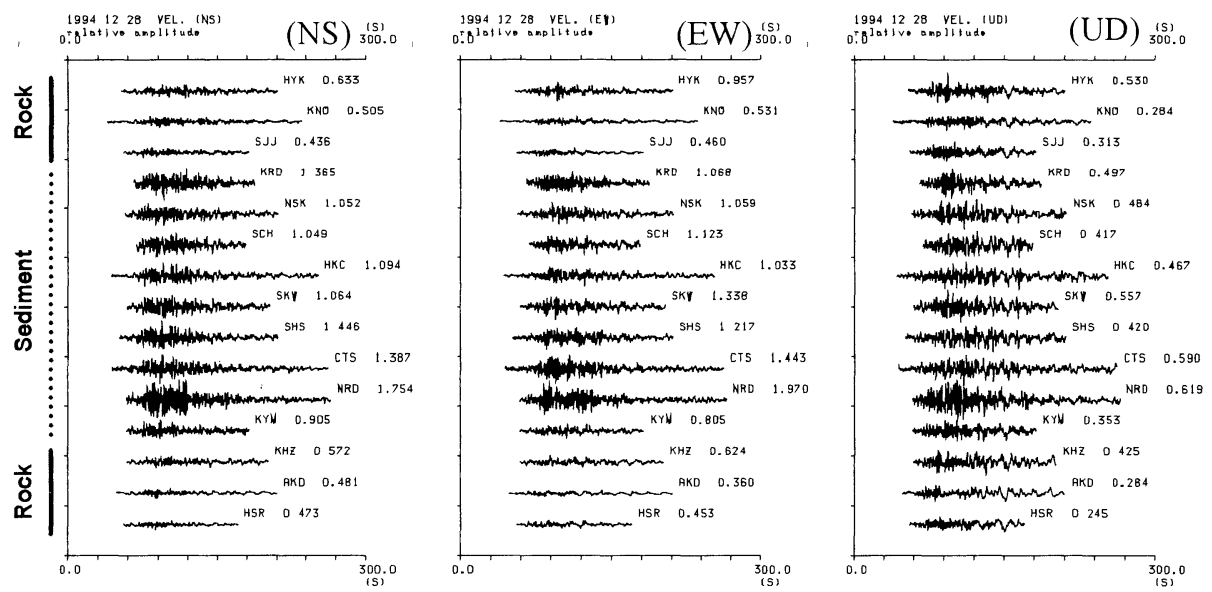

(d) 1994.12.28 Sanriku haruka-oki

Fig. 3. (continued)

(c) 1994 Hokkaido Toho-oki earthquake, (d) 1994 Sanriku haruka-oki earthquake. Each trace was integrated from original acceleration data in the frequency domain.

もっとあ遠い北海道東方沖地震が他に比べて若干大き い. $M$ が大きいということああるが，この地震による短 周期の励起が大きかったこと[例えば，SASATANI (1997)］を裏付けている。なお，いずれの記録でも加速 度は $125 \mathrm{~cm} / \mathrm{s} / \mathrm{s}$ に達していないため記録中のゲインレ ンジは一定である.

一般に加速度で見ると高周波数側の特徴が強調されて いる. Higashi and Kudo (1992) によって足柄平野の波 形に周期 5-8 秒の後続波群が確認されていることから, 速度波形を用いて記録の特徵を把握する. 数值積分で求 めた各地震の速度記象を Fig. 3 に示す. 数值積分は FFT を用いて周波数領域で行った. なお, 積分の際には 加速度フーリエスペクトルで見て SN 比のよい周波数帯
域を用いることとし, 釧路沖地震とウラジオストック付 近の地震では 0.05-20 Hz, 北海道東方沖地震では 0.02$20 \mathrm{~Hz}$ ，三陸はるか沖地震では 0.03-20 Hz のバンドパ スフィルターを用いた。 SN 比の評価は, 同じ装置で記 録した常時微動（ノイズ）のフーリエスペクトルと記録 のフーリエスペクトルを比較することにより周波数領域 で判断した. いずれの地震も $M$ が大きく, 地震動の継続 時間が長い，北海道東方沖地震の記録では，分散性が見 られる低周波 (約 $0.03 \mathrm{~Hz}$ ) の後続波が続いているが, 他 の地震ではそれほど特徴的な波群は見られない。ただ し，どの地震でも岩盤上の記録に比べ，平野内の記録で は高周波成分が強調されており, $\mathrm{S}$ 波初動からかなり遅 れて最大值を示す波形も多い。なお, 岩盤点と平野内観 
測点の最大速度の比 (2-3 倍) は, Table 3 に示した加速 度で見た場合（3-5 倍）に比べ若干小さくなっている. これは最大加速度值あるいは最大速度に影響を与える周

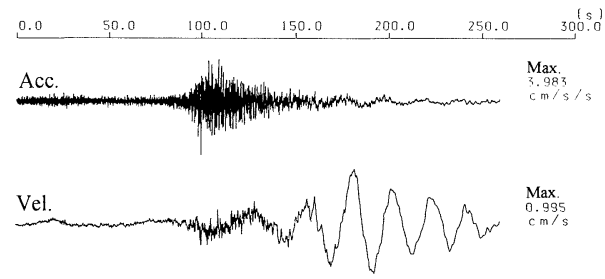

Fig. 4. Comparison of acceleration and velocity seismogram of 1994 Hokkaido Tohooki earthquake at HSR. Velocity seismogram was integrated from acceleration data in frequency domain.
波数帯域が異なるためと考えられる.

北海道東方沖地震の HSR での記録 (NS 成分) につい て，観測された加速度波形と速度波形を比較して Fig. 4 に示す. 加速度波形では速度波形に見られる低周波数で 大振幅の後続波群がほとんど見られない．明らかに速度 波形は, 加速度波形よりあ低周波数側の特徵を反映して いる. 北海道東方沖地震の波形では，この波群で最大值 が決まっており，速度波形では岩盤点と平野内観測点の 最大值にはほとんど差がない。

\section{§4. 解析}

\section{1 バンドパスフィルター波形の検討}

バンドパスフィルターを施した波形を用いて，周波数 帯域毎に足柄平野の地震動の空間変動を把握する.波形

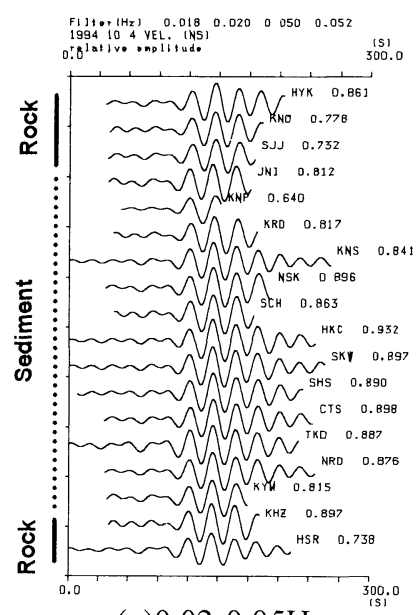

(a) $0.02-0.05 \mathrm{~Hz}$

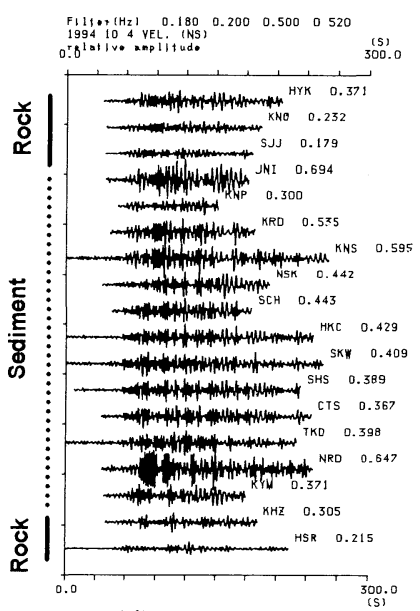

(d) $0.20-0.50 \mathrm{~Hz}$

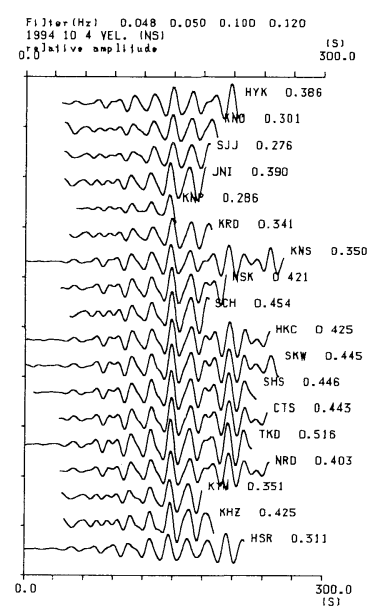

(b) $0.05-0.10 \mathrm{~Hz}$

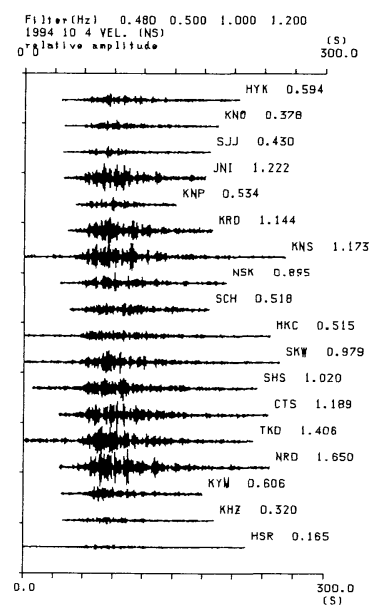

(e) $0.50-1.00 \mathrm{~Hz}$

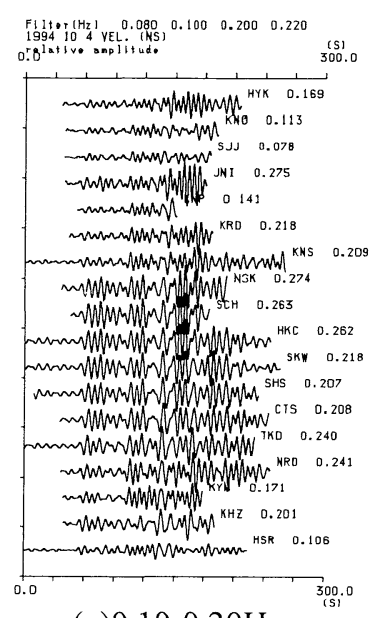

(c) $0.10-0.20 \mathrm{~Hz}$

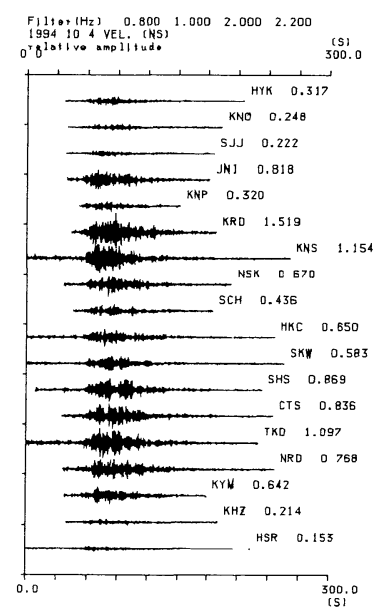

(f) $1.00-2.00 \mathrm{~Hz}$

Fig. 5. NS components of band-pass filtered velocity seismograms from the 1994 Hokkaido Toho-oki earthquake. Frequency bands of these traces are as follows; (a): 0.02-0.05 Hz, (b): $0.05-0.1 \mathrm{~Hz},(\mathrm{c})$ : $0.1-0.2 \mathrm{~Hz},(\mathrm{~d}): 0.2-0.5 \mathrm{~Hz},(\mathrm{e}): 0.5-1.0 \mathrm{~Hz},(\mathrm{f}): 1.0-2.0 \mathrm{~Hz}$. 
を直接比較することにより，振幅の変化ばかりでなく波 群の変化などについても検討できる.

低周波数側で最も SN 比のよい北海道東方沖地震の速 度波形（NS 成分）に周波数帯域 $0.02-0.05 \mathrm{~Hz}, 0.05-0.1$ $\mathrm{Hz}, 0.1-0.2 \mathrm{~Hz}, 0.2-0.5 \mathrm{~Hz}, 0.5-1.0 \mathrm{~Hz}, 1.0-2.0 \mathrm{~Hz}$ のバ ンドパスフィルターをかけた結果を Fig. 5 に示す. バン ドパスフィルターはFFTを用いて周波数領域で行い, 通過帯域の外側は 10-20\%の幅でコサイン型のテー パーを設けてある.

$0.1 \mathrm{~Hz}$ 以下の波形では, 平野内上の観測点で系統的に 振幅が大きいものの, どの観測点もほぼ同一の波形をし ており，特に $0.05 \mathrm{~Hz}$ 以下では振幅あほぼ等しい．この

\section{$0.05-0.1 \mathrm{~Hz}$}

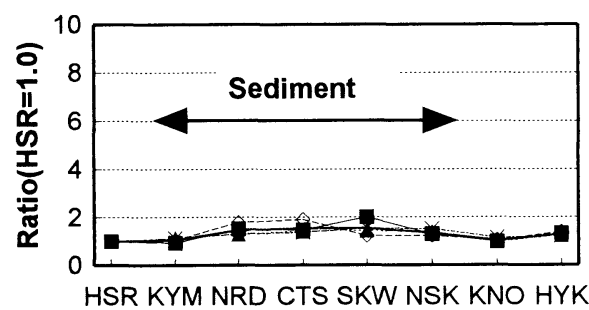

Station Code

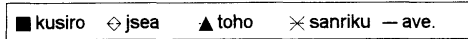

\section{$0.2-0.5 \mathrm{~Hz}$}

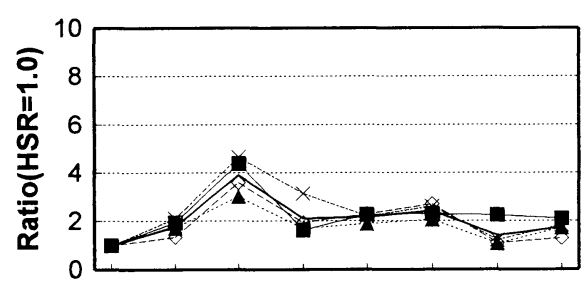

HSR KYM NRD CTS SKW NSK KNO HYK Station Code

- kusiro $\Leftrightarrow$ jsea $\Delta$ toho $\nsucc$ sanriku - ave.

\section{0-2.0Hz}

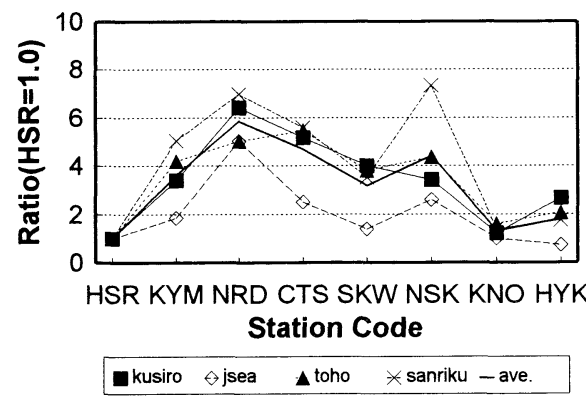

ような低周波数の地震動では盆地の規模に比べ波長が長 いため当然とあいえるが，一方で低周波数側までの SN 比の良さを示していると考えられる．0.1-0.2 Hz の波形 では，岩盤点に比べ平野内の観測点で振幅がさらに大き くなり，独立した波群が目立ち波形も異なってくる。な お，この帯域では，岩盤点である $\mathrm{KHZ}$ が振幅や波形の 点で平野内の観測点に近い挙動をしており, 逆に平野西 縁部の KRD, KNS, KNP は平野南部の観測点とは異な り岩盤点に似た波形をしている。 $0.2-0.5 \mathrm{~Hz}$ では各観測 点とも波形が複雑になり，岩盤点と平野部の波形・振幅 の違いは大きくなり，特にNRDや JNI では振幅が際 立って大きい.さらに高周波数側 $(0.5-1.0 \mathrm{~Hz}, 1.0-2.0$

\section{$0.1-0.2 \mathrm{~Hz}$}

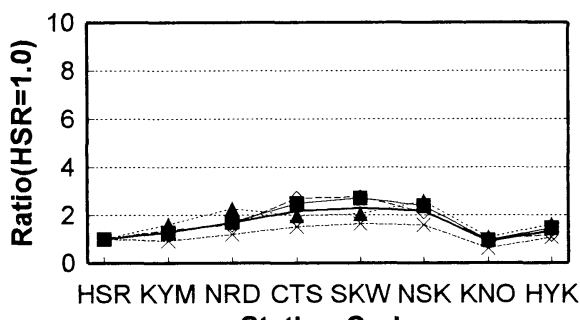

Station Code

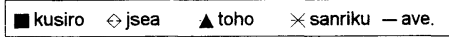

\section{$0.5-1.0 \mathrm{~Hz}$}

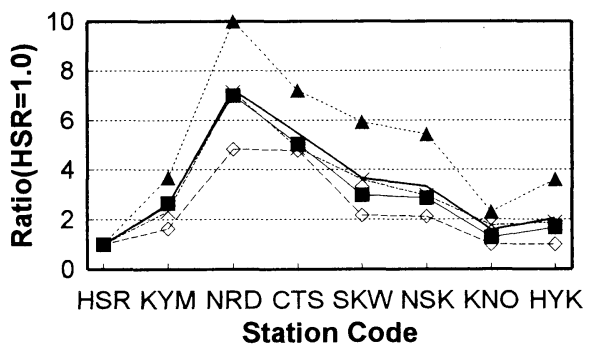

口usiro $\diamond$ jsea $\Delta$ toho $*$ sanriku - ave.

\section{0-5.0Hz}

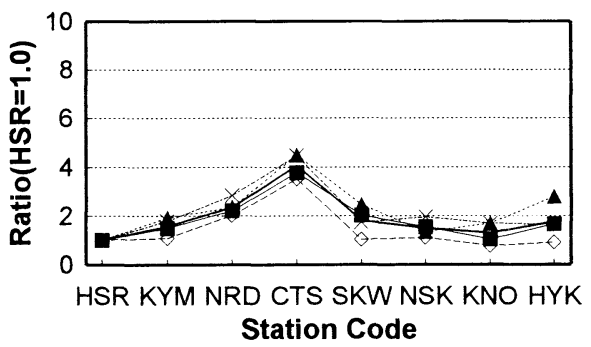

nusiro $\Leftrightarrow$ jsea $\Delta$ toho $\nsucc$ sanriku - ave.

Fig. 6. Maximum amplitude ratios of NS component of band-pass filtered seismogram with respect to HSR. 'kusiro', 'jsea', 'toho' and 'sanriku' denote 1993 Kushiro-oki eq., Near Vladivostok, 1994 Hokkaido Toho-oki eq. and 1994 Sanriku haruka-oki eq. respectively. 


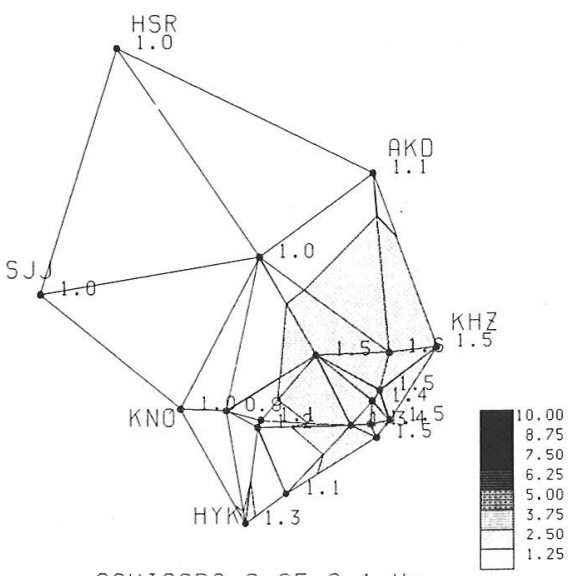

ASHIGARA $0.05-0.1 \mathrm{~Hz}$

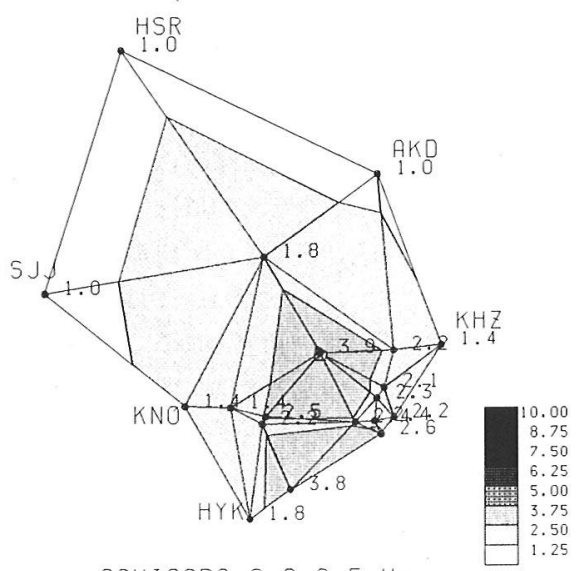

ASHIGARA $0.2-0.5 \mathrm{~Hz}$

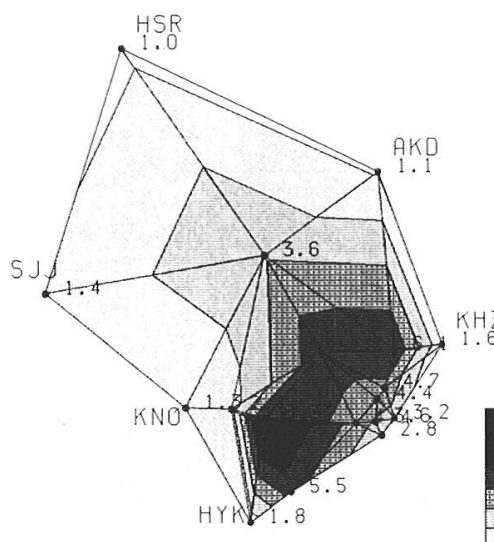

ASHIGARA $1.0-2.0 \mathrm{~Hz}$

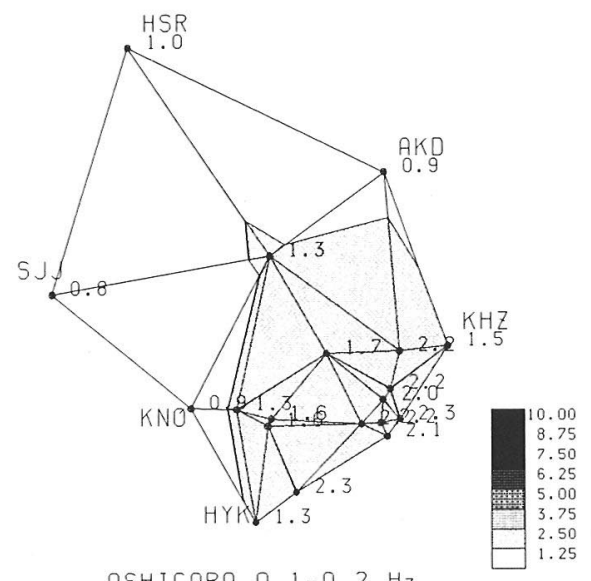

ASHIGARA $0.1-0.2 \mathrm{~Hz}$

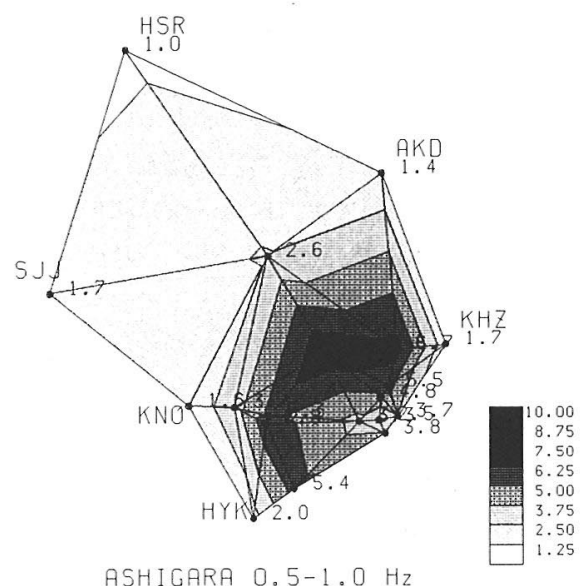

ASHIGARA $0.5-1.0 \mathrm{~Hz}$

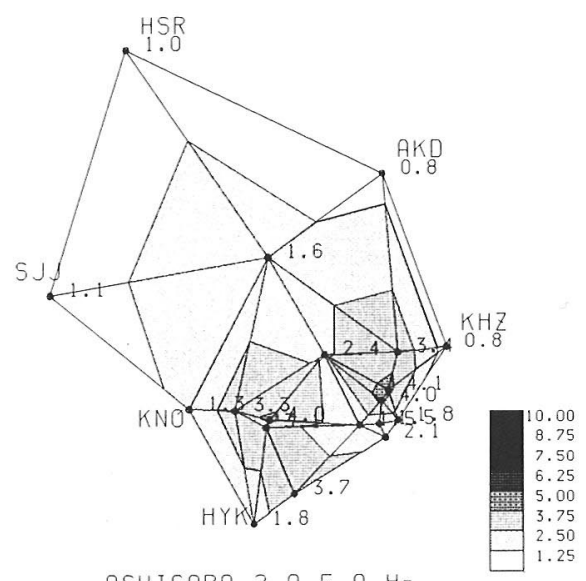

ASHIGARA $2.0-5.0 \mathrm{~Hz}$

Fig. 7. Spatial distribution of maximum amplitude ratios of NS component as a function of frequency bands. 
$\mathrm{Hz}$ ) では波形の相関は悪くなり，CTS と SHS のように 近接した観測点（約 $0.4 \mathrm{~km}$ ) でも波群の対応は不明瞭で ある. 平野内の観測点の振幅がかなり大きくなっている が, 足柄平野では沖積層の影響により周波数 $1 \mathrm{~Hz}$ 前後 の地震波が増幅され，また，この周波数の Love 波が卓 越することが指摘されている[KAWASE and SATO (1992), 笹谷・他 (1995)]. 0.5-1.0 Hz では, NRD, TKD, KRD, KNS, JNI の振幅が他に比べ大きくなっている.

1.0-2.0 Hz では, KRD, KNS, TKD の振幅が大きい。な お，他の地震記録に関しても，周期帯域毎の変化は同様 である.

一般に後続波群の発達による震動継続時間の延びが堆 積層上での波形の特徵の一つであるが, Fig. 5 の波形で は, 岩盤点でも継続時間が長く, 波形全体で見た場合, 平野内での継続時間の伸びは見られない。しかし，0.1$0.2 \mathrm{~Hz}$ の帯域波形を見ると対応する波群毎に継続時間 が伸び, 波形が複雑になっている事がわかる.

次に, 各周波数帯域毎の最大值の空間変動について検 討する. なお, 以下の検討では, 検討対象の 4 地震全て の記録が得られている岩盤点である HSR を基準点とし て各地点での最大振幅を HSR に対する比で表現する. まず, 地震毎にフィルター波形の最大振幅比がどのくら い変動しているかを確認しておく４４地震とも記録が得 られた観測点について, NS 成分のフィルター波形最大 值の比を Fig. 6 に示す. HSR, KNO, HYK は岩盤点, KYM, NRD, CTS, SKW, NSK は平野内の観測点であ る. 低周波数帯域 $(0.05-0.1 \mathrm{~Hz}, 0.1-0.2 \mathrm{~Hz})$ では各地点 の増幅および地震毎のばらつきも小さいが， $0.2-0.5 \mathrm{~Hz}$ では平野内の増幅がやや大きくなり, 特に観測点 NRD
が顕著となる. より高周波数の $0.5-1.0 \mathrm{~Hz}, 1.0-2.0 \mathrm{~Hz}$ では平野内での增幅が急激に大きくなり, 地震毎の差異 あ顕著となる．さらに高周波数 $(2.0-5.0 \mathrm{~Hz})$ では比が小 さくなり地震毎による差屯小さい. 特定の周波数帯域で 地震毎に応答が異なる事は, 入射角が異なる事に起因す ると考えられるが, 詳細は別の機会に検討する.

各周波数帯域波形の HSR に対する最大速度比 (NS 成分）の空間分布を Fig. 7 に示す. 地震毎に HSR に対 する比を求め, 各観測点で平均を求めた。 なお, 空間補 間は三角形をべースに観測点間を直線補間した。足柄平 野の観測網は, 空間的に均質な配置でないため, 観測点 間隔の粗い部分では不自然なところもあるが, 分布の概 略は把握できる。 $0.05-0.1 \mathrm{~Hz}, 0.1-0.2 \mathrm{~Hz}$ の範囲では, 平野南部の観測点で増幅が大きいが岩盤上でも平野内で も振幅比はそれほど変わらない. また, 岩盤点でも $\mathrm{KHZ}$ と HYK が若干大きい. この帯域の分布形状はこの地域 の重力・ブーゲー異常 [例えば, 大久保・他 (1992) ] 之 相似形を示しており, 地下深部の構造との関係がうかが われる. $0.2-0.5 \mathrm{~Hz}$ や 0.5-1.0 Hz では, 平野内の各観測 点の値がさらに大きくなるが, 特に NRD, TKD での増 幅が大きい. また, $1.0-2.0 \mathrm{~Hz}$ では平野南西部の KNS, $\mathrm{KRD}$ の 2 点の増幅が顕著となる. 周波数 $1 \mathrm{~Hz}$ 前後で は, 平野最南部の観測点を取り囲む地域の観測点の振幅 がかなり大きくなっている，2.0-5.0 Hzでは，全体的に 1.0-2.0 Hz に比べ小さな值を示しているが, CTS 付近 や KNS 付近では相対的に大きく, 振幅の大きい地域が 2 分極している. 観測点の密度の高い平野南部では, 高 周波数側で複雑な増幅挙動を示しており, 極表層の地質 構造が影響していると考えられる。なお， $\mathrm{EW}$ 成分は

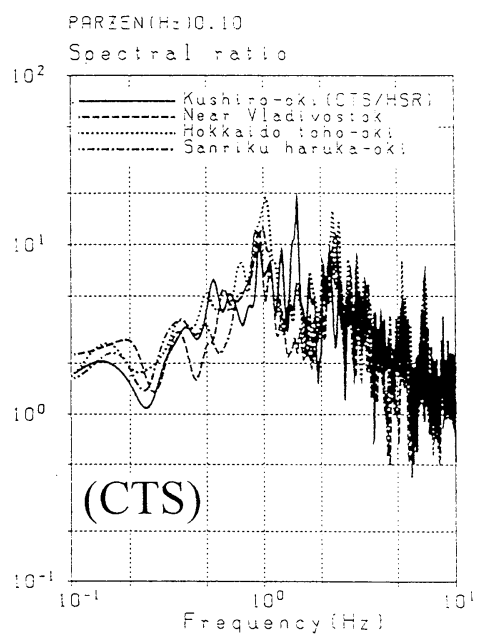

Fig. 8. Variation of Fourier spectral ratio with respect to HSR. The figures show the ratios of NS component for four earthquakes. 
0.5-1.0 Hz, 1.0-2.0 Hz で KNS, KRD 付近の比が小さく なる他は NS 成分と同様な傾向を示す.

\section{2 フーリエスペクトル比の検討}

観測された記録のスペクトル $O(f)$ は次のように表現 される.

$O(f)=S(f) P(f) G(f) I(f)$

ここで, $S(f)$ は震源項, $P(f)$ は伝播経路の影響, $G(f)$ は 観測点特性, $I(f)$ は観測計器の特性, $f$ は周波数である. 今回用いた記録では，地震毎の $S(f), P(f), I(f)$ は，ぞの 観測点でもほぼ共通と考えられるので，各観測点のスペ クトルと基準点のスペクトルとの比により，相対的な観 測点特性が抽出できる. なお, 観測点特性を求めるスペ クトルとして水平 2 成分のベクトル合成值を用いたり [例えば，KATo et al. (1992)]，NS, EW を組み合わせた 複素数として扱う場合 [Lu et al. (1992), 中村 (1995), STEIDL et al.(1996)]ああるが，ここでは，NS, EW の間 の相異についてむ着目するために別々に取り扱った。 ま
た，フーリエスペクトルの計算に当たっては， $\mathrm{S}$ 波部分 を対象とした。ただし，堆積盆地内の観測点の波形が特 に後続波群の励起に特徵があることから，震源の破壊継 続時間に限定せず，記録として共通に使える区間を用い た。したがって，得られた観測点特性は堆積層の 1 次元 的な応答特性とは必ずし屯一致しない，なお，記録波形 には $\mathrm{P}$ 波部分はほとんど含まれていないので $\mathrm{P}$ 波部分 の影響は少ない。なお，スペクトル比の基準点としては フィルター波形の最大值の検討と同様に HSR を用い る.

まず，検討したデータに対するスペクトル比の安定性 を確認する，HSR を当面の基準点として岩盤点 HYK と平野内の CTS のスペクトル比を Fig. 8 に示す. 細か い点では相違も見られるが，両地点とも今回検討対象と した 4 地震に関してはスペクトル比の形状は安定して いる. 以下では, 各観測点での 4 地震のスペクトル比の 平均 [以下，平均スペクトル比と記す.] で特性を評価
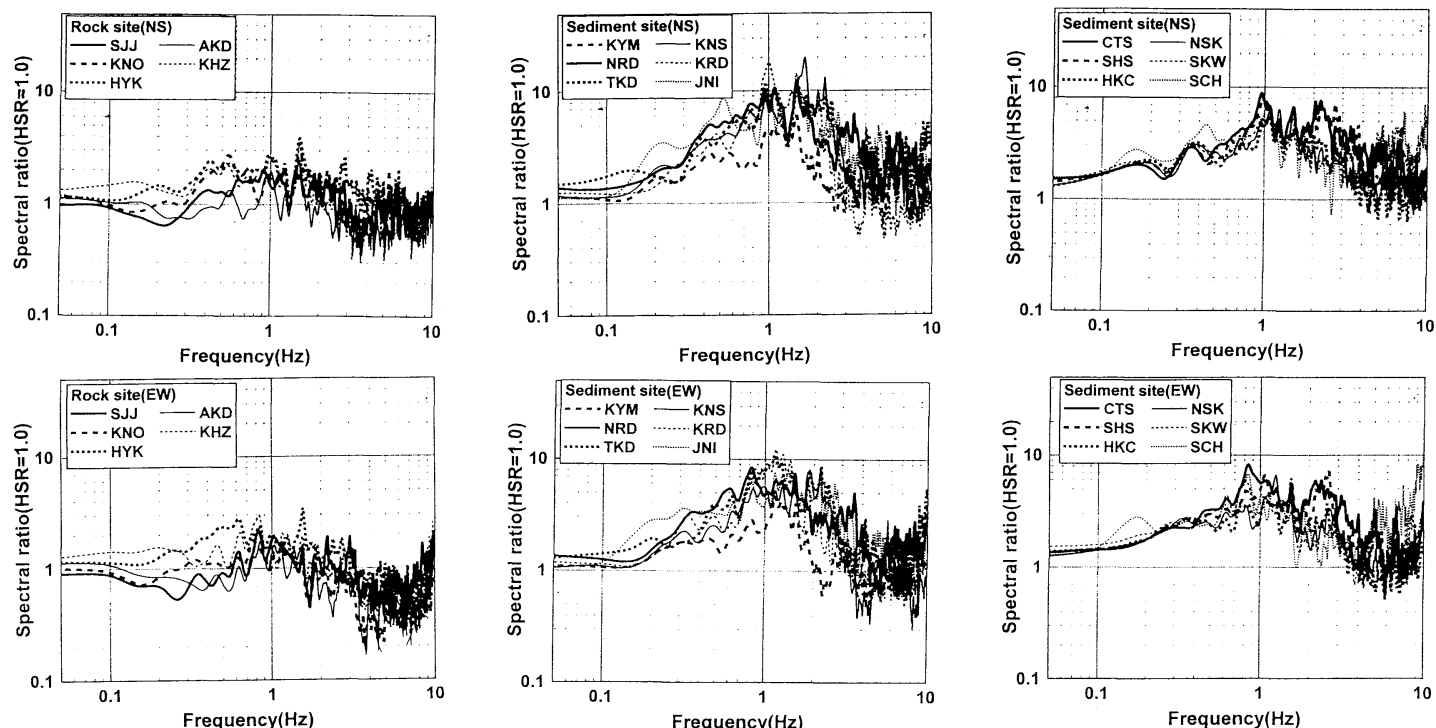

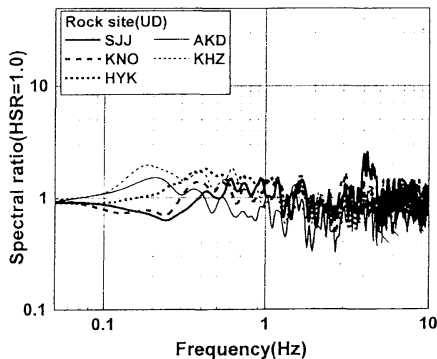

(a)

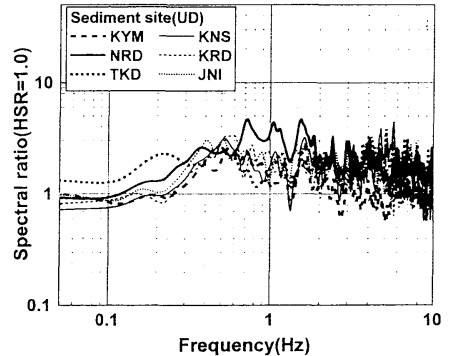

(b)

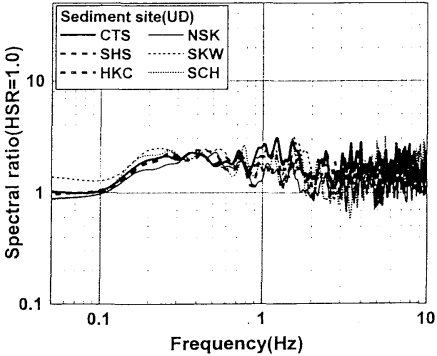

(C)

Fig. 9. Average of four earthquakes' Fourier spectral ratios of each site with respect to HSR. These spectral ratio were smoothed by Parzen window of $0.1 \mathrm{~Hz}$ width. (a): rock sites, (b): sediment sites in central part and margin of Ashigara valley, (c): sediment sites in south part of Ashigara valley. 
する.

平均スペクトル比の検討にあたっては，Fig. 7 に見ら れる特徴を考慮し, 平野周辺の岩盤観測点, 平野端部地 域及び平野中央の観測点, そして平野最南部の観測点の 3 つのグループに分けて検討する，まず，HSR に対する 各岩盤点 (SJJ, KNO, HYK, KHZ, AKD) での平均スペク トル比を Fig. 9(a) に示す. 観測点毎に差はあるが岩盤 点ではスペクトル比は概ね 0.5-2.0 の範囲内にある.こ の值は後で示す沖積層上の観測点に比べ有意に小さい. 特に $0.1 \mathrm{~Hz}$ 以下ではさらに違いは小さく $10 \%$ 以内で ある.また $5 \mathrm{~Hz}$ を越えるとどの観測点も 1.0 倍程度以 下となる. 各観測点の特徴としては, KHZ が 0.1-0.2 Hz 前後で大きく, 後述する平野南東部の観測点群と同レ心゙ ルであること, AKD の UD 成分が $0.2 \mathrm{~Hz}$ 前後で大きい こと, SJJ が 3 成分とあ $0.2-0.3 \mathrm{~Hz}$ で谷となっているこ となどが挙げられる。

次に, 平野中央部の $\mathrm{KYM}, \mathrm{NRD}$ 及び平野端部に近い TKD, KNS, KRD, JNI での平均スペクトル比を Fig. 9(b) に示す.なお，KNPについては，1 地震しか記録がない ため示していない. どの観測点もスぺクトル比の值は, $0.1 \mathrm{~Hz}$ 以下では 1 に近いが, $0.2 \mathrm{~Hz}$ 以上の帯域では岩 盤点に比べ大きい. 水平動の $0.2-2.0 \mathrm{HZ}$ の範囲では 210 倍, 上下動では $2-5$ 倍となっており, UD 成分の方が 全体的に増幅が小さい. また, $3-4 \mathrm{~Hz}$ 前後からレベルが 下がるが，これは Fig. 9(a) で見た岩盤点之同様の傾向 であり HSR の高周波数の振幅レベルが相対的に高い之 判断される.この図に示した観測点は KYM を除き，ス
ペクトル比の大きい帯域が広いのが特徴である。なお， 各観測点とも NS, EW 両成分の形状は必ずしも一致し ない. KUDO and WANG (1992) は, KNS の KNOに対す る比が NS, EW 両成分で一致しないことを指摘してい るが，ここであ同様な傾向が見られる．さらに，比較的 近い（約 $250 \mathrm{~m}$ ) KNS と KRD の 2 点で NS 成分のピー ク位置がずれている (KNS: 約 $1.5 \mathrm{~Hz}, \mathrm{KRD}: 1.0 \mathrm{~Hz}$ )こ とから，この帯域ではかなりローカルな影響が強いこと がわかる。

最後に, 平野南部の CTS, NSK, SHS, HKC, SKW, $\mathrm{SCH}$ での平均スペクトル比を Fig. 9(c) に示す. 全体的 に岩盤点に比ベレベルが高く, 水平動では各観測点とも $1 \mathrm{~Hz}$ 付近にピークが見られる。地域的に狭い理由ああ るが，スペクトル比の形状はどの成分も観測点間の差が 小さい，水平両成分の形状は似ているが，NS成分の方 が低周波数側で山谷が見られる. Fig. 9(b) と比較すると $\mathrm{TKD}$ 之同様, 低周波数側の值が大きく, 水平動では 0.2 $\mathrm{Hz}$ 付近で 2 倍に達している. $0.3 \mathrm{~Hz}$ 以上では Fig. 9(b) の KYM を除く各点の方がレベルが高い，また，UD成 分は $0.2 \mathrm{~Hz}$ 付近で急に持ち上がって $0.3 \mathrm{~Hz}$ 程度までは 平野南部の観測点の方がレベルが高い.

以上から, HSR に対する平均スペクトル比の主な特 徵をまとめると以下のようになる.

(1) $0.1 \mathrm{~Hz}$ 程度以下の低周波数側ではどの観測点も ほぼ同じスペクトル振幅となるが, 高周波数側では岩盤 上の観測点間にも差が見られる. 岩盤上の観測点の值は 0.05-10 Hz の範囲では概ね 0.5-2 倍の間にあるが, 平
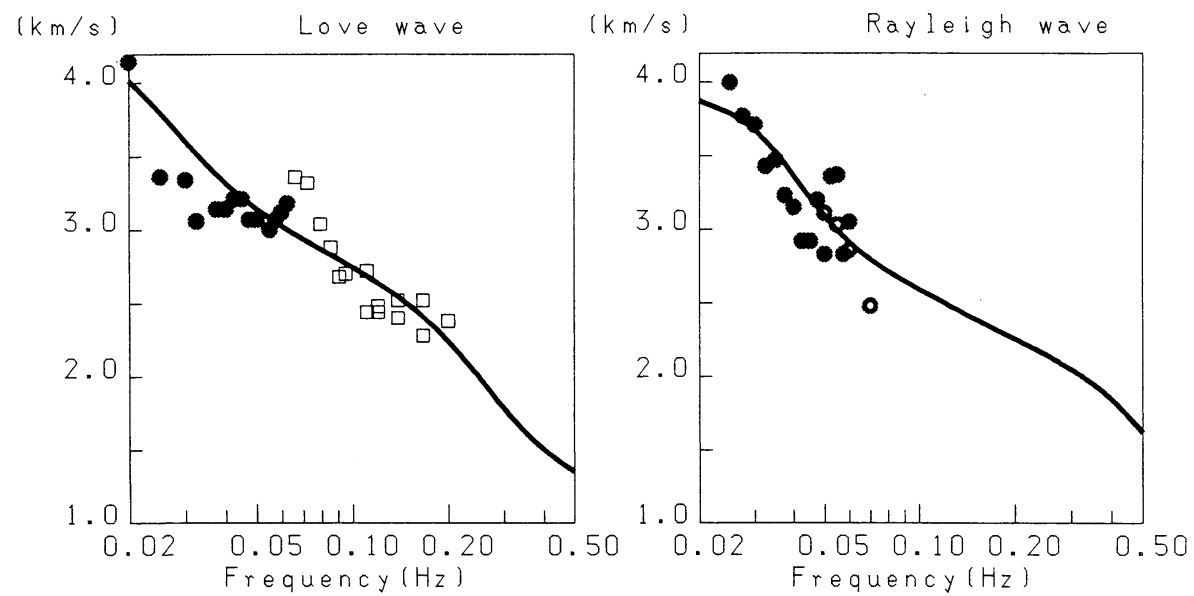

Fig. 10. Phase velocities of surface waves in and around Ashigara valley.

Left: Love wave, Right: Rayleigh wave. Closed circles denote the estimated velocities from the data of 1994 Hokkaido Toho-oki earthquake. Open circles denote the estimated velocities from the data of 1994 Sanriku haruka-oki earthquake. Open squares denote the velocities after HigAsHi and Kudo (1992). Bold lines show the phase velocities of fundamental mode of Love and Rayleigh waves. 
野内の観測点では, $0.2-0.5 \mathrm{~Hz}$ の範囲で 2 倍以上, $1 \mathrm{~Hz}$ 前後では最も大きく 10-20 倍になっている.

(2) 平均スペクトル比の空間変動について以下のこ とが指摘できる. $0.2 \mathrm{~Hz}$ 付近のレベルは系統的に変化し ており，平野の南東に向かって大きくなる，0.5-1.0 Hz 付近のレベルは平野中央部の NRD や平野周辺部の JNI, KRD, KNS, TKD が大きい.

(3) 平野南部の観測点のように $1 \mathrm{~km}$ 程度離れてい ても平均スペクトル比の形状が $2-3 \mathrm{~Hz}$ まで似ている場 合ああるが，KNS，KRD 観測点の NS 成分のようにご く近傍（約 $250 \mathrm{~m}$ ）の観測点同士でも $1 \mathrm{~Hz}$ 程度以上で 形状が異なる場合があるなど，高周波数側の増幅には局 所的な影響が強い.

(4) HSR に対する平野部におけるスペクトル比の形 状は NS, EW 両成分で必ずしも一致しない.

\section{3 深部構造亡地震動特性}

北海道東方沖地震の 3 成分波形及び三陸はるか沖地 震の UD 成分波形には, 卓越周波数 $0.1 \mathrm{~Hz}$ 以下の分散 性を示す波群が見られた[Fig. 3(c), (d)]. そこで，狭帯 域のガウス型バンドパスフィルターをかけた波形にセン ブランス解析 [NEIDELL and TANER (1971)]を適用し， 波群の伝播速度（位相速度）及び方向を求めた。 なお， HATAYAMA et al. (1995) では孤立化した波群に対し 3 成 分を同時に用いたセンブランス解析を適用しているが, ここでは, Transverse 成分とUD成分について別々に 解析を行った. 北海道東方沖地震の解析には, 欠測 2 点

Table 4. Deep ground structure model of Ashigara valley.

\begin{tabular}{ccccc}
\hline No. & $\begin{array}{c}\mathrm{Vp} \\
(\mathrm{km} / \mathrm{s})\end{array}$ & $\begin{array}{c}\text { Vs } \\
(\mathrm{km} / \mathrm{s})\end{array}$ & $\begin{array}{c}\text { Density } \\
(\mathrm{g} / \mathrm{cm} 3)\end{array}$ & $\begin{array}{c}\text { Thickness } \\
(\mathrm{km})\end{array}$ \\
\hline 1 & 2 & 0.6 & 1.8 & 0.1 \\
\hline 2 & 2.5 & 1.1 & 2.1 & 0.4 \\
\hline 3 & 3 & 1.5 & 2.3 & 0.8 \\
\hline 4 & 4.2 & 2.4 & 2.5 & 2 \\
\hline 5 & 5.5 & 2.8 & 2.5 & 6.5 \\
\hline 6 & 6.15 & 3.1 & 2.7 & 14.6 \\
\hline 7 & 6.7 & 3.7 & 2.88 & 16.9 \\
\hline 8 & 8 & 4.5 & 3.28 & - \\
\hline
\end{tabular}

と SJJ, JNI, KNP, KNS, KRD, SCH, CTS, SKW を除い た 10 点を, 三陸はるか沖地震では岩盤点 6 点に平野中 央部の NRD をあわせた 7 点の記録を用いた. センブラ ンス解析から求めた位相速度を Fig. 10 に示す。黒丸が 北海道東方沖地震, 白丸が三陸はるか沖地震の結果であ る. Transverse 成分を Love 波, UD 成分を Rayleigh 波の分散曲線と比較した。 また，解析した波群の伝播方 向は，ほぼ震央方向からであった。なお，図中の四角は HIGASHI and Kudo (1992) が 1989 年伊豆半島東方沖の 地震及び 1990 年伊豆大島近海地震に対して求めた位相 速度である. 図中の実線は Table 4 の地下構造に対して 求めた Love 波及び Rayleigh 波の位相速度（基本モー ド）である. Table 4 のモデルは, 表層は HigAsHi and Kudo (1992) を, 深部は MiKUMo (1966) のモデルを参 考にし，試行錯誤的に分散性状に合うように作成した. 表層の第 1 , 第 2 層分が, 平野内の第四紀の堆積層に相 当する.

表層の影響を見るために, Table 4 のモデル (Case 0) から表層の 2 層分を除いたモデル (Case 1), 3 層分を除 いたモデル (Case 2) で, Love 波基本モードの位相速

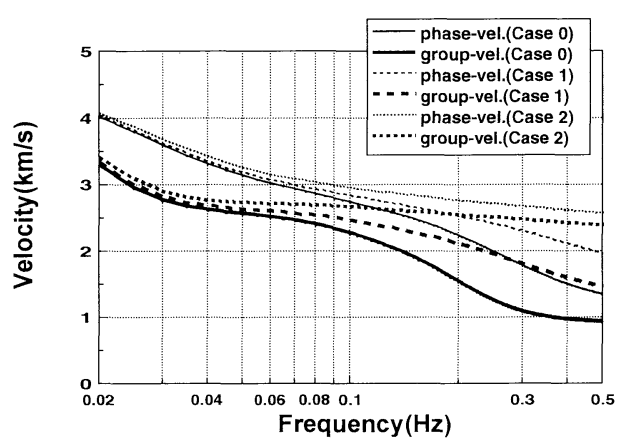

Fig. 11. Effects of surface layers on fundamental Love wave velocities.

In Case 0 , the structural model in Table 4 was used for velocity calcuration. In Case 1 , the model removed two surface layers from the Case 0's model was used. In Case 2 , the model removed three surface layers from the Case 0's model was used.

Table 5. Study case for 1-D amplification.

\begin{tabular}{cccccccccc}
\hline No. & $\begin{array}{c}\text { Vs } \\
(\mathbf{k m} / \mathrm{s})\end{array}$ & $\begin{array}{c}\text { Density } \\
(\mathrm{g} / \mathrm{cm} 3)\end{array}$ & $\begin{array}{c}\text { Thickness }(\mathrm{km}) \\
\text { model-a }\end{array}$ & model-b & model-c & model-d & \multicolumn{1}{c}{ model-e } & model-f \\
\hline 1 & 0.6 & 1.8 & 0.1 & 0 & 0.1 & 0 & 0 & 0 \\
\hline 2 & 1.1 & 2.1 & 0.4 & 0 & 0.4 & 0 & 0 & 0 \\
\hline 3 & 1.5 & 2.3 & 0.8 & 0.8 & 0 & 0.8 & 1.5 & 0 \\
\hline 4 & 2.4 & 2.5 & 2 & 2 & 2 & 3 & 2 & 2 \\
\hline 5 & 2.8 & 2.5 & - & - & - & - & - & - \\
\hline
\end{tabular}




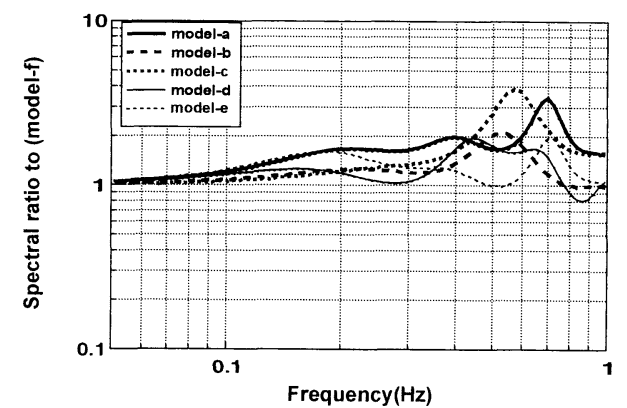

Fig. 12. Spectral ratio of each model's amplification factor to model-f.

Each structure model is shown in Table 5.

度・群速度を計算し Fig. 11 に示す. 表層の有無の影響 は $0.1 \mathrm{~Hz}$ を超えるとかなり大きくなり, $0.3 \mathrm{~Hz}$ 付近の 群速度で見るとCase 1 の場合で速度差約 $0.7 \mathrm{~km} / \mathrm{s}$, Case 2 の場合で速度差約 $1.5 \mathrm{~km} / \mathrm{s}$ となって見れてく る.このことは, 平野周辺の岩盤点と平野内部の堆積層 上観測点の波形が $0.1-0.2 \mathrm{~Hz}$ を境に大きく異なってく ることに対応している.

さらに, 周波数 0.1-0.2 $\mathrm{Hz}$ での最大速度比や平均ス ペクトル比に系統的な空間変化が見られたことから，低 周波数側の 1 次元的な増幅を検討する. Table 4 の $V_{\mathrm{s}}=$ $2.8 \mathrm{~km} / \mathrm{s}\left(V_{\mathrm{p}}=5.5 \mathrm{~km} / \mathrm{s}\right)$ 層を基盤と考え, Table 5 に 示したモデルで表層の影響を検討する. model-a は平野 南部の堆積層上観測点, model-c は平野西部の表層の薄 い観測点, model-b, d, e は堆積岩上の観測点, model-f は基準点と考える．それぞれに対する $\mathrm{S}$ 波の鉛直入射に よる 1 次元応答を model-f に対する比で表したものが Fig. 12 である. $0.2 \mathrm{~Hz}$ 付近が比較的大きいのは, model-a, e であり, 第 4 層が厚い model-d でそれほど 大きくないことから, $0.2 \mathrm{~Hz}$ 付近の值に影響が大きいの は $V_{\mathrm{s}}=1.5 \mathrm{~km} / \mathrm{s}$ 層以浅の厚さであることがわかる、 ス ペクトル比の検討で基準とした HSR の近傍では，道路 建設用の爆破の観測（爆破点を含め 3 点）を基に $V_{\mathrm{p}}=$ $4.4 \mathrm{~km} / \mathrm{s}, V_{\mathrm{s}}=1.4 \mathrm{~km} / \mathrm{s}$ という值が推定されている [Kudo and Shima (1988)]. Table 4 における $V_{\mathrm{p}}$ 構造か らすれば model-f に近いと見なせるが， $V_{\mathrm{s}}$ で見れば $V_{\mathrm{s}}=1.5 \mathrm{~km} / \mathrm{s}$ 層が薄い状態と判断できる. 大久保・他 (1992) は, HigASHI (1989), 笠原・他 (1991) 等の検討結 果やプレートの沈み込み形状を基に $V_{\mathrm{p}}=4 \mathrm{~km} / \mathrm{s}$ 相当 層の深さを, 東に傾く基盤としてモデル化し, ブーゲー 異常を説明している．本論文で示した低周波数側の振幅 比も同様な傾向を示しており, $V_{\mathrm{s}}=1.5 \mathrm{~km} / \mathrm{s}$ 層以浅の 表層厚変化を考慮した 1 次元的增幅効果でも定性的に は説明できる。
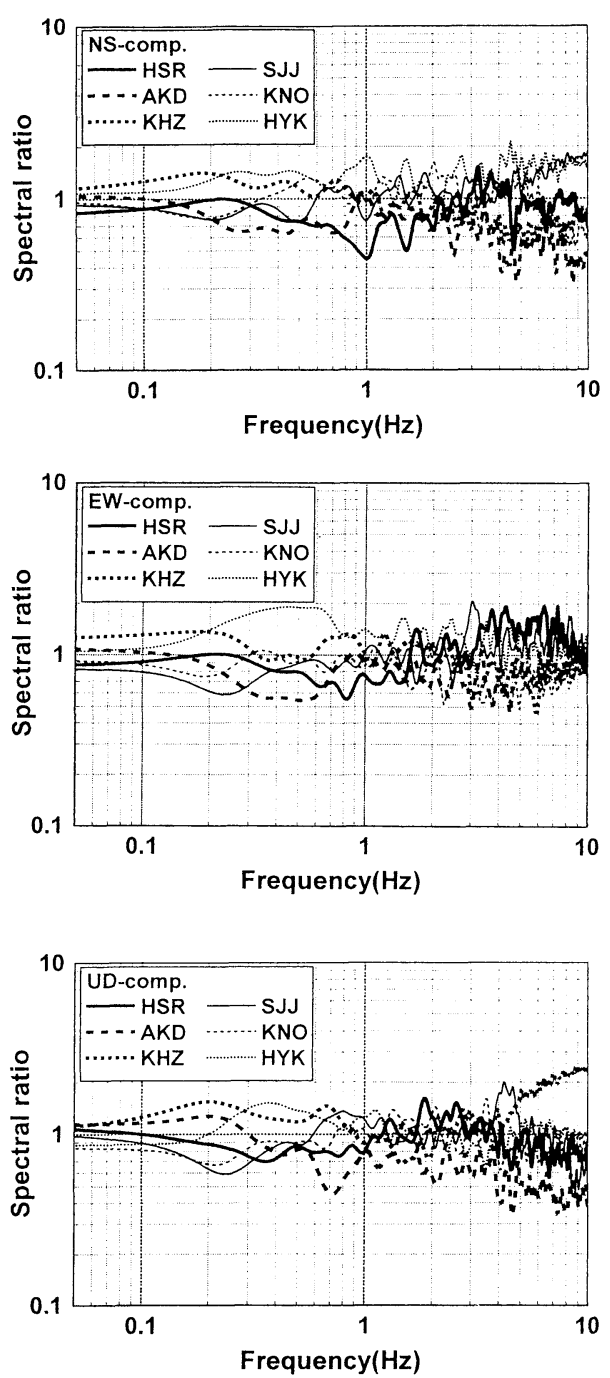

Fig. 13. Fourier spectral ratios of rock site spectra to the average spectrum in case of 1994 Sanriku haruka-oki earthquake. These spectra were smoothed by Parzen window of $0.1 \mathrm{~Hz}$ width.

\section{§5. 議論}

\section{1 基準観測点としての岩盤観測点}

岩盤観測点での地震動特性の把握は, 平野への入射波 の基準点を考える上で重要である．足柄平野を取り巻く 丘陵地の露頭岩はそれぞれ岩質が異なり，HSR に対す るスペクトル比 (Fig. 9(a)) は, 平野内と比べれば值が 1 に近いものの岩盤点同士であ特性が異なっている。ここ では，すべての岩盤点で記録が得られている三陸はるか 沖地震について, 岩盤上観測点のスペクトルの平均值を 求め, それに対する各観測点の比 (Fig. 13)について検 討する，平均に対するスペクトル比のばらつきは，ほぼ 
0.5-2.0 倍の範囲に収まっており, 特に, 周波数 $0.07 \mathrm{~Hz}$ 未満の低周波数側で見ると0.8-1.2 倍の範囲内である. この傾向はFig. 7 に示したHSR に対する比の地震毎の ばらつきから見て他の地震記録でも大きく変わらないと 考えられる.また，今回基準とした HSR は，細かく見れ ば水平動の $1 \mathrm{~Hz}$ 付近が小さめで, NS 成分の 3-4 Hz, $\mathrm{EW}$ 成分の $4 \mathrm{~Hz}$ 以上でやや大きい. HSR を基準とした スペクトル比 (Fig. 9) から， $3 \mathrm{~Hz}$ 付近から高周波数側で HSRのスペクトルが大きい，つまり増幅されている可 能性を述べたが，この点の解明に関しては, 岩盤の風化 による影響の評価 [STEIDL et al. (1996)] や表層の不整形 性の評価 [KATo et al. (1992)] が必要と考えられる. 観测 点毎の傾向を見ると, $0.2 \mathrm{~Hz}$ 付近までは, 相対的に KHZ が大きい. また， $0.3 \mathrm{~Hz}-1.0 \mathrm{~Hz}$ では HYK が相対 的に大きい. この点については Fig. 12 で示したように 深部の地下構造と関係していると考えられる. STEIDL et $a l .(1996)$ は, 表層付近の風化等の影響を避けるために, 基準点として岩盤の地中点を用いることを提案している が, 足柄平野の様に周辺岩盤が一様でない場合は, 単に 地中に基準を移しただけでは不十分であり，表層の影響 を回避するために深部までの構造を考える必要がある.

TAKEMURA et al. (1991) によれば，周波数 1-5 Hz で の入射波に対する増幅率は花崗岩 $\left(V_{\mathrm{s}}=2000-2700 \mathrm{~m} /\right.$ s) で 2-3, 先第三紀の堆積岩層 $\left(V_{\mathrm{s}}=1000-1600 \mathrm{~m} / \mathrm{s}\right)$ で 2-6, 第三紀層 $\left(V_{\mathrm{s}}=500-800 \mathrm{~m} / \mathrm{s}\right)$ で 5-20, 洪積層 $\left(V_{\mathrm{s}}=\right.$ 約 $\left.450 \mathrm{~m} / \mathrm{s}\right)$ で 8-30, 沖積層 $\left(V_{\mathrm{s}}=\right.$ 約 $\left.200 \mathrm{~m} / \mathrm{s}\right)$ で約 40 となっている. 今回の結果は, HSR を基準とし
て岩盤点で 1-2, 堆積層 (沖積層) 上で 5-10 となってい る. HSR は, 第三紀の角碩凝灰岩で $V_{\mathrm{s}}=1400 \mathrm{~m} / \mathrm{s}$ と推 定され [KUDo and SHIma (1988)], KNO は, 第四紀の安 山岩質熔岩で $V_{\mathrm{s}}=800 \mathrm{~km} / \mathrm{s}$ [JESG (1991)] である. 他 の点も岩質を考えれば同程度の $V_{\mathrm{s}}$ 值と推定され，岩盤 点相互の比も, HSR と沖積層上の観測点との比も TAKEMURA et al. (1991) の結果のばらつきの範囲内にある.

一般に, 平野に対する地震動評価の基準点を考える場 合, 最も増幅が少なく, 局所的な影響の少ない点を選ぶ ことが望ましい，足柄平野の場合，岩盤点である $\mathrm{KHZ}$ の 0.1-0.2 Hz での振幅が, $V_{\mathrm{s}}=1.5 \mathrm{~km} / \mathrm{s}$ 以下の層の存 在に強く影響されていると考えられることから, 山間部 を含む足柄地域の地震動を議論する際には $V_{\mathrm{s}}=2.5$ $\mathrm{km} / \mathrm{s}$ 程度の地壳上部を基盤と考える必要がある.

\section{2 スペクトル比の安定性}

基準観測点を用いた経験的な地震動評価の安定性を評 価するために，遠距離の大規模地震によって得られたス ペクトル比と比較的近距離の地震のスペクトル比を比較 する. 東・工藤 (1989) は, 震央位置の異なる比較的近い 中小規模地震の記録 [1988 年伊豆東方沖 $(M=5.2, H=$ $5 \mathrm{~km}, \Delta=35 \mathrm{~km}), 1987$ 年千葉県東方沖地震 $(M=6.7$, $H=58 \mathrm{~km}, \Delta=117 \mathrm{~km}), 1987$ 年山梨県東部 $(M=4.8$, $H=32 \mathrm{~km}, \Delta=27 \mathrm{~km})]$ から, $0.4 \mathrm{~Hz}$ 以下では入射方向 により堆積層上での増幅が異なると述べている.しか し，彼らの検討ではデータの制約から地震毎に基準点が 異なり，また十分低周波数側まで SN 比が良いデータで はなかった，そこで，ここでは同一の岩盤点と堆積層上

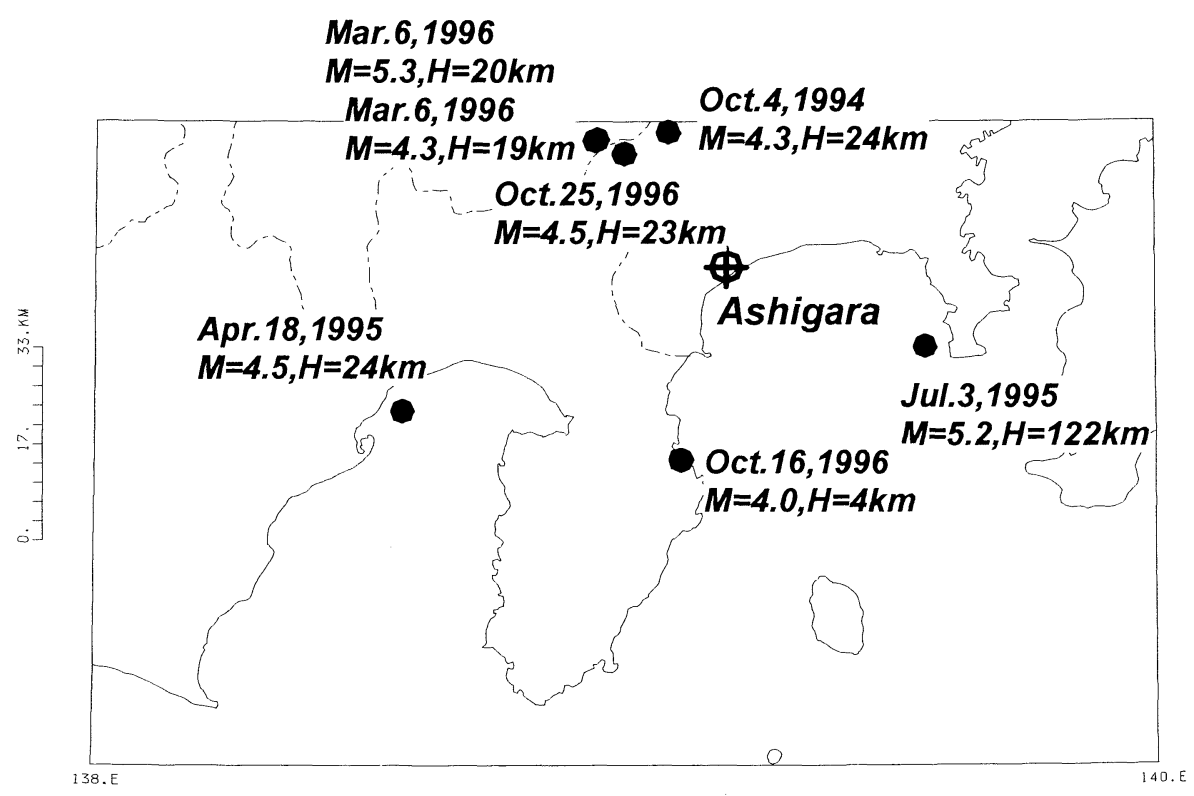

Fig. 14. Location map of short distance earthquake epicenters. 
Table 6. Short distance earthquakes used in this study.

Origin time $(\mathrm{y} / \mathrm{m} / \mathrm{d} h: \mathrm{m}: \mathrm{s})$ Latitude Longitude depth $M$ Region

$\begin{array}{lllllll}1994 / 10 / 04 & 02: 56: 00.4 & 35.480 \mathrm{~N} & 139.078 \mathrm{E} & 24 \mathrm{~km} & 4.3 & \text { Eastern Yamanashi Pre. } \\ 1996 / 03 / 06 & 23: 12: 27.6 & 35.471 \mathrm{~N} & 138.946 \mathrm{E} & 19 \mathrm{~km} & 4.3 & \text { Eastern Yamanashi Pre. } \\ 1996 / 03 / 06 & 23: 35: 28.7 & 35.473 \mathrm{~N} & 138.951 \mathrm{E} & 20 \mathrm{~km} & 5.3 & \text { Eastern Yamanashi Pre. } \\ 1996 / 10 / 25 & 12: 25: 17.6 & 35.452 \mathrm{~N} & 139.005 \mathrm{E} & 23 \mathrm{~km} & 4.5 & \text { Eastern Yamanashi Pre. } \\ 1995 / 04 / 18 & 20: 26: 25.2 & 35.062 \mathrm{~N} & 138.588 \mathrm{E} & 24 \mathrm{~km} & 4.5 & \text { Northern Suruga bay Reg. } \\ 1995 / 07 / 03 & 08: 53: 23.2 & 35.162 \mathrm{~N} & 139.567 \mathrm{E} & 122 \mathrm{~km} & 5.2 & \text { Sagami bay Reg. } \\ 1996 / 10 / 16 & 22: 58: 57.4 & 34.975 \mathrm{~N} & 139.119 \mathrm{E} & 4 \mathrm{~km} & 4.0 & \text { E off Izu Pen. (Ito-oki) }\end{array}$

Source parameters are taken from Japan Meteorological Agency.

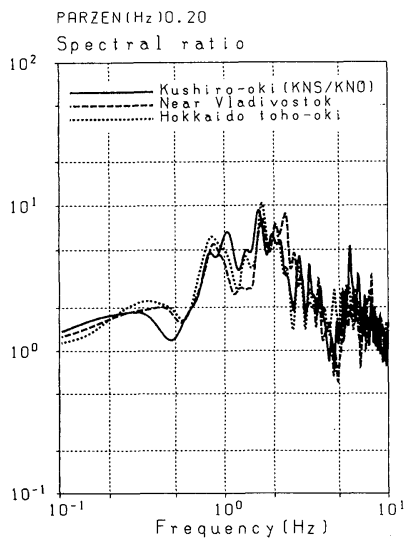

(a)

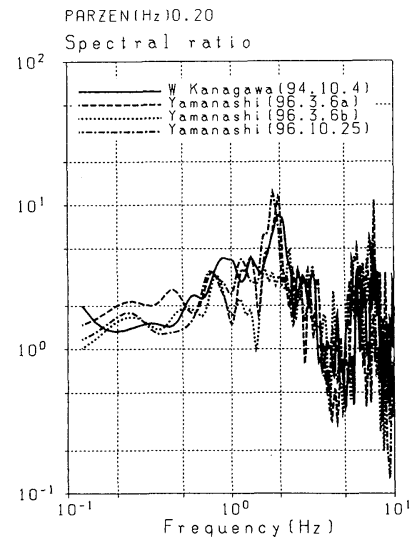

(b)

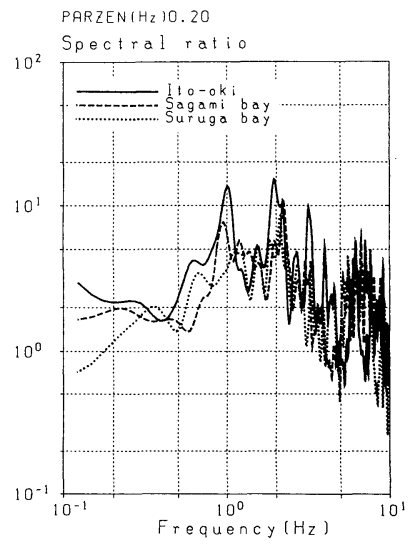

(c)

Fig. 15. Variation of spectral ratios of sediment site (KNS) to rock site (KNO). These spectra were smoothed by Parzen window of $0.2 \mathrm{~Hz}$ width. (a): very far earthquakes, (b): east part of Yamanashi, (c): other region.

の点の比で地震每のスペクトル比を作成し，震源位置に よるスペクトル比の違いを確認する．検討に用いた記録 は, Fig. 2, Table 3 の遠距離大規模地震に加えて Fig. 14, Table 6 に示す足柄平野を取り囲む中小規模地震の 記録である.ここでは基準点を $\mathrm{KNO}$ とし，平野内の点 としては KNOに比較的近い KNS とする.

$\mathrm{KNO}$ と KNSのS 波部分 40 秒間のスペクトル比 （NS 成分）を Fig. 15 に示す. それぞれ遠距離大規模地 震 (a), 山梨県東部の地震群 (b), その他の地震 (c) であ る. 遠距離地震の場合は, ばらつきは少なく, $1 \mathrm{~Hz}$ と 2 $\mathrm{Hz}$ 付近の 2 つのピークが明瞭である. (b) のスペクトル 比では，(a), (c) で見られる $1 \mathrm{~Hz}$ 付近のピークが見られ ない. また， $4-5 \mathrm{~Hz}$ 付近が他より小さい傾向があるが,
これは松岡・他 (1997) が小田原市街地を対象としたア レイ観測で示した結果と同様な傾向である。また，(c)の 中では駿河湾の地震む $1 \mathrm{~Hz}$ のピークが見られないな ぞ， $1 \mathrm{~Hz}$ のピークが出る地震と出ない地震がある. (a) の結果では，ピークが多少にぶっているが，平均的な性 状に近い．しかし，特定の基準観測点に対する比で地震 動特性を表現した場合, 震源によっては特定のピークが 強く出る，あるいは出ないなどの偏差があることは留意 しておくべきである.

\section{§6. まとめ}

観測点から見て非常に遠距離で発生した地震の記録を 用いて, 足柄平野の観測点のサイト特性を検討し, 以下 
のような点を明らかにした。

(1) $0.1 \mathrm{~Hz}$ 程度以下の周波数帯域では, 岩盤点も平 野内の観测点もほぼ同じ波形・振幅を示す。しかし, 0.1 $\mathrm{Hz}$ 以上では, 平野内の観測点は岩盤点に比べ複雑な増 幅挙動を示す。ただし，平野東側の岩盤点 KHZ は 0.1 $0.2 \mathrm{~Hz}$ 程度では平野内の点と同等である.このような低 周波数帯域での複雑な挙動には, $V_{\mathrm{s}}=1.5 \mathrm{~km} / \mathrm{s}$ 層以浅 の層が強く影響しており，山間部を含む足柄地域の地震 動を統一的に議論するためには $V_{\mathrm{s}}=2.5 \mathrm{~km} / \mathrm{s}$ 程度の地 殻上部を基盤と考える必要がある. また，その基盤深さ は, 平野の南部では $1.5 \mathrm{~km}$ 程度の深さと考えられる.

(2) バンドパスフィルター波形の最大值は, $0.2 \mathrm{~Hz}$ 以下の低周波数帯域では, 平野南東部に向かって一様に 大きくなるが，より高周波数側では振幅の大きな地点が 局在化してくる. 低周波数側の変化には基盤深さの変化 が対応し, 高周波数側の変化には平野内部の沖積層厚の 変化に対応していると考えられる.

(3) 岩盤点相互のスペクトル比は, $0.07 \mathrm{~Hz}$ 程度以下 では $20 \%$ 程度のばらつきであるが， $0.1 \mathrm{~Hz}$ 以上の周波 数帯域では, スペクトル振幅に最大 0.5-2 倍の差が見ら れる.

(4) 岩盤点に対する平野内の地点のスペクトル比は, $0.1 \mathrm{~Hz}$ 以上では 2-10 倍程度の值を示し，1-2 Hz 付近 のピークが特徴的である.

（5） NS，EW 両成分の基準点に対するスペクトル比 は必ずしも一致しない.これは, $2 \cdot 3$ 次元の波動伝播の 影響と考えられる.

なお, 震源の位置によりスペクトル比が変化したり, 水平 2 成分の比が異なる事は, 震源特性や足柄平野の $2 \cdot 3$ 次元構造の影響と考えられる.これらの点につい ては，今後検討を進める予定である.

\section{謝辞}

足柄平野におけるデータは, 高橋正義・東京大学地震 研究所助手, 坂上 実・同技術官の観測網の維持管理に 関する多大な努力よって得られたものです。また，査読 していただいた野越三雄・秋田大学教授, 笹谷 努・北 海道大学助教授のコメントは本稿の改善に役立ちまし た. 記して感謝いたします。

\section{文献}

Field, E. H. and K. H. ЈАсов, 1995, A comparison test of various site-response estimation techniques, including three that are not reference-site dependent, Bull. Seism. Soc. Am., 85, 1127-1143.

Hatayama, K., K. Matsunami, T. Iwata and K. IriKURA, 1995, Basin-induced Love waves in the east- ern part of the Osaka basin, J. Phys. Earth, 43, 131155.

Higashi, S., 1989, Underground structure beneath the Ashigara Valley, Japan, Proceeding of the National Symposium on Effects of Surface Geology on Seismic Motion, 199-206.

東 貞成・工藤一嘉, 1989, 足柄平野における地震動特 性. Proceedings of the National Symposium on Effects of Surface Geology on Seismic Motion, 319324.

Higashi, S. and K. Kudo, 1992, Polarization and frequency-wavenumber spectrum analysis for the strongmotion array data in Ashigara valley, Japan, J. Phys. Earth, 40, 5-25.

干場充之 - 堀家正則 - 出射隆文 - 岩田知孝, 1988, 地表 付近の地質構造の地震動への影響一堆積盆地上での地 震動の解析と数值計算一, 地震 $2,41,195-202$.

石橋克彦，1993，小田原付近に発生した歴史地震とその 地学的意義, 地学雑誌, 102, 341-353.

岩田知孝・入倉孝次郎, 1986, 観測された地震波から震 源特性・伝播経路特性及び観測点近傍の地盤特性を分 離する試み, 地震 $2,39,579-593$.

Japanese National Working Group on the Effects of Surface Geology on Seismic Motion (JESG), 1991, Ashigara Valley Blind Prediction Test.

笠原敬司・山水史生・井川 猛・清水祥四郎, 1991, 足 柄平野～国府津・松田断層を横切る地震波反射断面, 地震学会予稿集, No. 2, 324 .

Kato, K., M. Takemura, T. Ikeura, K. Urao and T. UETAKe, 1992, Preliminary analysis for evaluation of local site effects from strong motion spectra by an inversion method, J. Phys. Earth, 40, 175-191.

Kaw Ase, H. and T. SAto, 1992, Simulation analysis of strong motions in the Ashigara valley considering one- and two-dimensional geological structures, J. Phys. Earth, 40, 27-56.

木下繁夫・御子柴正・星野 務, 1986, 堆積層におりる 短周期 S 波の平均的増幅特性の推定, 地震 $2,39,67-$ 80.

Kitagawa, Y., I. Okawa and T. Kashima, 1988, Dense strong motion earthquake seismometer array at site with different topographic and geologic conditions in Sendai, Proc. of 9th World Conf. Earthq. Eng., Vol. 2, 215-220.

Kudo, K., E. Shima and M. Sakaue, 1988, Digital strong motion accelerograph array in Ashigara valley, Proc. of 9th World Conf. Earthq. Eng., Vol. 8, 119-124.

Kudo, K. and E. Shima, 1988, Installation of strong motion seismographs, plan for geotechnical measurements at Ashigara valley site effects test area, Japan, Proc. of IASPEI/IAEE Joint Working Group on Effects of Surface Geology on Seismic Motion, 2nd Workshop, Tokyo.

Kudo, K. and Y. SAwAdA, 1992, Blind prediction experiments at Ashigara Valley, Japan, Proc. of 10th World Conf. Earthq. Eng., 6967-6971. 
KuDo, K. and Z. WANG, 1992, A preliminary analysis of strong motion records in Ashigara valley test site; and errata, in Int. Symp. Effects of Surf. Geol. on Seismic Motion, ESG1992, Odawara, Japan, 3, 15-18.

Langston, C. A., 1979, Structure under Mount Rainier, Washington, inferred from teleseismic body waves, J. Geophys. Res., 84, 4749-4762.

Lu, L., F. Yamazaki and T. Katayama, 1992, Soil amplification based on seismometer array and microtremor observation in Chiba, Japan, Earthq. Eng. Struct. Dyn., 21, 95-108.

松岡昌志・翠川三郎・内山泰生, 1997, 小田原市内での 強震観測とそれに基づく地震動特性の検討, 地震 2 , 50, $1-10$.

Mikumo, T., 1966, A study on crustal structure in Japan by the use of seismic and gravity data, Bull. Earthq. Res. Inst., 44, 965-1007.

中村 晋, 1995, ベクトルスペクトルによる地震動の増 幅特性評価とその適用, 土木学会論文集, No. 519/I$32,161-173$.

Neidell, N. S. and M. T. TANer, 1971, Semblance and other coherency measures for multi channel data, Geophysics, 36, 482-497.

大久保修平・長沢 工・平賀士郎・田島広一・萩原幸 男, 1992, 南関東活断層の重力調査 (I)一国府津一松田 断層一, 地震研彙報, 67, 325-359.

Omote, S., K. Ohmatsuzawa and T. Ohta, 1980, Recently developed strong motion earthquakes instruments array in Japan, Proceedings of 7 th World Conference on Earthquake Engineering, 2, 41-48.

Pitilakis, K. (coordinator), 1995, EUROSEISTEST Volvi-Thessaloniki, A European Test-Site for engineering seismology, earthquake engineering and seismology, Project: EV5V-CT93-0281.

Real, C. E. and B. E. Tucker, 1988, Turkey Flat, USA site effects test area site characteristics, Proc. of IASPEI/IAEE Joint Working Group on Effects of Surface Geology on Seismic Motion, 2nd Workshop, Tokyo.

笹谷 努・松島 健・小柳敏郎, 1990, 十勝平野におけ る強震動観測, 北海道大学地球物理学研究報告, 54 , 15-22.

笹谷 努・齋藤誠治・古村美津子 - 工藤一嘉, 1995 , や や深発地震による足柄平野の地震応答, 北海道大学地 球物理学研究報告, 58,21-37.

Sasatani, T., 1997, Source characteristics of the 1994 Hokkaido Toho-Oki Earthquake deduced from wide band strong motion records, Journal of the Faculty of Science, Hokkaido University Series VII (Geophysics), 10, No. 2, 269-293.

Steidl, J. H., A. G. Tumarkin and R. J. Archulata, 1996, What is a reference site?, Bull. Seism. Soc. Am., 86, No. 6, 1733-1748.

Takemura, M., K. Kato, T. Ikeura and E. Shima, 1991, Site amplification of S-Waves from strong motion records in special relation to surface geology, J. Phys. Earth, 39, 537-552.

Wen, K.-L., H.-Y. Peng and L.-F. Liu, 1995, Basin effects analysis from a dense strong motion observation network, Earthq. Eng. Struct. Dyn., 24, 10691083.

山本みよ゙り・岩田知孝・入倉孝次郎, 1995, 釧路気象台 における強震動と弱震動に対するサイト特性の評価, 地震 2, 48, 341-351.

YAMAZAKI, H., 1992, Tectonics of a plate collision along the northern margin of Izu peninsula, central Japan, Bulletin of the Geological Survey of Japan, 43, 603-657. 